\title{
45 Males and 94 Females Undergoing Chronic Peritoneal Dialysis: Comparison and Correlation of Their Dialytic Treatment and Body Composition
}

\author{
Giancarlo Ruggieri
}

\begin{abstract}
A wide selection of data of 45 males versus those of 94 females were compared and correlated with 11 variables selected from the available variables. The estimation of creatinine clearance by the Cockroft formula was studied in depth, and both its significant correlation with measured clearances and its overestimation were noted. Scores were attributed to the $p$ values of performed correlations to mathematically compare the correlations. The magnitude of the dispersion of the scores was evaluated by the ratio mean of the scores/standard deviation, which is the width of the range of the significance of the correlations, thus providing the relevance of the correlations for each basal variable. Lean Body Mass (LBM) was calculated, using the Boer formula as well as the serum creatinine, and it was shown that LBM was strongly related to the body structure represented by BMI. The study of total body water (TBW) showed its significantly greater size in males, but it has a significantly greater size in females as a percentage of body weight . This results in a greater dry mass in males and greater body water with respect to weight in females. No differences between males and females resulted from age, the relationship of weight/height in terms of BMI, or the efficacy of treatment. It was concluded that 1) age is relevant in estimating the size of creatinine clearance, as shown by the creatinine clearance via Cockroft, but it overestimated the creatinine clearance; 2) Lean Body Mass is proportional to BMI; 3) the variability of statistical significance in a correlation is well defined by the scores values; and 4) dry mass is significantly greater in males, while body water is greater in females in terms of percentage of weight.
\end{abstract}

Index Terms - Cockroft, lean body mass, body water

\section{INTRODUCTION}

Premise - A previous paper studied the body composition, biologic residual functions and dialytic treatment of 20 males and 19 females undergoing chronic peritoneal dialysis, with particular attention to body water and its distribution as intracellular and extracellular water [1]. The aim of the present paper is to compare a wide selection of data of 45 males versus those of 94 females, fundamentally concerning dialytic treatment and creatinine mass, as real dialytic treatment and as actual mass or ideal mass of creatinine, differently indexed on BSA or BMI. The two studies, based on different subjects, constitute in their entirety a study of the different aspects of body composition in patients undergoing chronic peritonea dialysis, with particular care paid to the comparison of males versus females.

Giancarlo Ruggieri, past Director of Nephrology Unit and Director of the Department of Nephrology and Urology, Hospitals San Giacomo and ONRM, Roma, Italy

\section{METHOD}

This study is based on 40 variables, including : age, height, weight, BSA, BMI, creatininemia, creatinine clearance according to Cockroft (Cockroft), Cockroft per week, dialysis volume, dialysis volume/min, dialysis volume 100 , total creatinine clearance/week, normalized creatinine clearance according to age, total excreted creatinine/die, ideal excreted creatinine according to weight, ideal creatinine according to height corrected by weight, delta Cockroft minus total excreted creatinine, delta creatinine clearance, delta $\%$, delta creatinine clearance $/ \mathrm{kg}$, positive delta creatinine clearance, actual creatinine clearance + delta positive/week, creatinine clearance by ideal creatinine according to weight and age, creatinine clearance by ideal creatinine according to height and age/week, not corrected creatinine clearance/BSA, not corrected creatinine clearance/BMI, total excreted creatinine/BMI, excreted creatinine/BSA, ideal excreted creatinine corrected according to age/BMI, ideal excreted creatinine/BSA, excreted creatinine/weight, total excreted creatinine/creatininemia, total excreted creatinine/ideal excreted creatinine by weight, excreted creatinine by Cockroft/BMI, and excreted creatinine by Cockroft/BSA. The first step was a comparison of the variables for males versus females. The following step was the correlation of 11 basal variables versus the remaining 29 variables. The comparison and the correlations were performed by the statistic software MINITAB 18, Minitab, State College, PA, USA; a T test for two variables was used for comparison, and the statistic test Pearson was used for correlations, thus restituting the degree of correlation and its significance (p greater or lower than 0.05 ).

The basal variables were age, height, weight, BSA,BMI, creatininemia, Cockroft, dialysis volume, total creatinine clearance week, total excreted creatinine/die, and ideal creatinine clearance according to height and age; they have been selected because they were found in the database and were not indexed by other variables. The variable "ideal creatinine clearance according to height and age" is not ideal creatinine clearance indexed on age and height, it is the theoretical value of the creatinine clearance waited for age and height in healthy individuals.

\section{RESULTS}

The comparison of the data

Tables I, II, III, and IV show the results of comparing the data of males versus those of females. The results that did not have a significant difference are highlighted in bold. 


\begin{tabular}{|c|c|c|c|c|c|c|}
\hline & \multicolumn{4}{|c|}{ Table I - Comparison of males versus females } & & \\
\hline & $\mathrm{n}$ & Variables & $\mathrm{T}$ value & $\mathrm{p}$ & & \\
\hline & 1 & age & 0.7 & 0.484 & & \\
\hline & 2 & height & 7.52 & 0.000 & & \\
\hline & 3 & weight & 6.86 & 0.000 & & \\
\hline & 4 & BSA & 2.16 & 0.033 & & \\
\hline & 5 & BMI & 1.97 & 0.053 & & \\
\hline & 6 & creatininemia & 3.03 & 0.003 & & \\
\hline & 7 & Cockroft & 1.41 & 0.162 & & \\
\hline & 8 & Cockroft week & 1.34 & 0.183 & & \\
\hline & 9 & Dialysis volume & 1.34 & 0.183 & & \\
\hline & 10 & $\begin{array}{c}\text { Dialysis } \\
\text { volume/min }\end{array}$ & 2.99 & 0.004 & & \\
\hline \multicolumn{7}{|c|}{ Table II - Comparison of males versus females } \\
\hline $\mathrm{n}$ & \multicolumn{4}{|l|}{ Variables } & $\begin{array}{c}\mathrm{T} \\
\text { value }\end{array}$ & $\mathrm{p}$ \\
\hline 11 & \multicolumn{4}{|c|}{ Dialysis volume/100 } & 3.42 & 0001 \\
\hline 12 & \multicolumn{4}{|c|}{ Total creatinine clearance week } & 2.59 & 0.012 \\
\hline 13 & \multicolumn{4}{|c|}{ Normalized creatinine clearance by age } & 3.64 & 0.000 \\
\hline 14 & \multicolumn{4}{|c|}{ Total excreted creatinine/die } & 2.72 & 0.008 \\
\hline 15 & \multicolumn{4}{|c|}{ Ideal excreted ct by weight } & 14.35 & 0.000 \\
\hline 16 & \multicolumn{4}{|c|}{ Ideal creatinine according to height corrected on weight } & 10.8 & 0.000 \\
\hline 17 & \multicolumn{4}{|c|}{ Delta Cockroft .creatinine - total excreted $\mathrm{Ct}$} & $2^{-2.2}$ & 0.03 \\
\hline 18 & \multicolumn{4}{|c|}{ Delta of creatinine clearance } & $6^{-3.4}$ & 0.001 \\
\hline 19 & \multicolumn{4}{|l|}{ Delta \% } & 0.2 & 0.843 \\
\hline 20 & \multicolumn{4}{|c|}{ Delta creatinine clearance $/ / \mathrm{kg}$} & $5^{-6.9}$ & 0.000 \\
\hline
\end{tabular}

The comparisons in Table II, numbers 18, 19, and 20 include the terms Delta, Delta \% and Delta creatinine clearance $/ \mathrm{kg}$. "Delta" is the difference between two sizes, in this case, the difference between the measured creatinine clearance and the theoretic standard size of the waited clearance on the basis of age and of gender.

\begin{tabular}{|l|l|c|c|}
\hline \multicolumn{2}{|l}{ Table III - Comparison of males versus females } & \multicolumn{2}{l|}{} \\
\hline $\mathrm{n}$ & Variables & value & $\mathrm{p}$ \\
\hline 21 & Positivized delta creatinine clearance & -2.05 & 0.043 \\
\hline 22 & Positivized delta creatinine clearance/kg & -3.72 & 0.000 \\
\hline $\mathbf{2 3}$ & Actual creatinine clearance/delta non-positivized week & $\mathbf{- 0 . 1 7}$ & $\mathbf{0 . 8 6 2}$ \\
\hline 24 & Actual creatinine clearance plus delta positivized week & 2.42 & 0.018 \\
\hline 25 & Creatinine clearance by ideal creatinine according to age, week & 5.01 & 0.000 \\
\hline 26 & Creatinine clearance by ideal creatinine according to height, age, week & 5.05 & 0.000 \\
\hline $\mathbf{2 7}$ & Cockroft week/BSA & $\mathbf{- 1 . 5 3}$ & $\mathbf{0 . 1 3 1}$ \\
\hline $\mathbf{2 8}$ & No corrected l creatinine clearance /BSA & $\mathbf{0 . 5 4}$ & $\mathbf{0 . 5 9 2}$ \\
\hline $\mathbf{2 9}$ & No corrected creatinine clearance /BMI & $\mathbf{1 . 8 6}$ & $\mathbf{0 . 0 6 7}$ \\
\hline $\mathbf{3 0}$ & Cockroft week/BMI & $\mathbf{0 . 5 9}$ & $\mathbf{0 . 5 5 9}$ \\
\hline
\end{tabular}


World Journal of Research and Review (WJRR) ISSN:2455-3956, Volume-7, Issue-3, September 2018 Pages 32-52

\begin{tabular}{|c|c|c|c|}
\hline \multicolumn{4}{|c|}{ Table IV - Comparison of males versus females } \\
\hline $\mathrm{n}$ & Variables & $\begin{array}{c}\mathrm{T} \\
\text { value }\end{array}$ & $\mathrm{P}$ \\
\hline 31 & Total excreted creatinine /BMI & 5.96 & 0.000 \\
\hline 32 & Excreted Creatinine/BSA & 5.51 & 0.000 \\
\hline 33 & Ideal excreted creatinine by weight corrected on age/BMI & 9.19 & 0.000 \\
\hline \multicolumn{4}{|c|}{ Table IV - Comparison of males versus females - following data) } \\
\hline 34 & Ideal excreted creatinine by weight corrected on age/BSA & 9.29 & 0.000 \\
\hline 35 & Excreted creatinine/weight & 4.71 & 0.000 \\
\hline \multicolumn{4}{|c|}{ Table IV - Comparison of males versus females - following data } \\
\hline 36 & Ideal excreted creatinine corrected on age/height & 9.61 & 0.000 \\
\hline 37 & Total excreted Ct/ creatininemia & 3.8 & 0.000 \\
\hline 38 & Total excreted creatinine/ideal excreted creatinine by weight & $\mathbf{0}$ & 1 \\
\hline 39 & Excreted creatinine by Cockroft/BMI & 4.35 & 0.000 \\
\hline 40 & Excreted creatinine by Cockroft/BSA & 2.56 & 0.013 \\
\hline
\end{tabular}

Twelve variables out of forty had no significant differences in the comparison of males versus females: age, BMI, Cockroft, Cockroft week, dialysis volume, delta \%, actual creatinine clearance/delta non-positivized week, Cockroft week/BSA, no corrected creatinine clearance/BSA, no corrected creatinine clearance/BMI, Cockroft week/BMI, and total excreted creatinine/ideal excreted creatinine by weight. Considering on a whole the significance of the not-different variables, males and females have very similar age, similar body structure (because of the not-different BMI), and similar efficacy of treatment.

The estimated creatinine clearance according to the Cockroft formula and the measured clearances.

The clearance estimated according to Cockroft [2] is calculated as follows: [(140 - age) x weight in kg] / (72 x creatininemia in $\mathrm{mg} / \mathrm{dl}$ ). The values of weight and creatininemia are significantly greater in males, as expected, whereas the values of age are very close between males and females. The relevant difference in the formula of 2 variables out 3 seems in contradiction with the insignificant difference of the Cockroft values for males versus females. A step-by-step analysis of the Cockroft calculation explicated its equality between males and females. The formula 140 - age x weight resulted in significantly different values between males and females, $63223.5 \pm 1391.5$ versus $5620.5 \pm 1280$, $\mathrm{T}$ value $=4.32, \mathrm{p}=0.000$, as well as the calculation of $72 \mathrm{x}$ creatininemia, which resulted in $785.2 \pm 239.4$ versus $652.5 \pm 173.6$, $\mathrm{T}$ value $=4, \mathrm{p}=0.000$. Based on the ratio $140-$ age $\mathrm{x}$ weight $/ 72 \mathrm{x}$ creatininemia, the values of Cockroft resulted in $8.54 \pm 2.53$ versus $8.54 \pm 2.31$, $\mathrm{T}$ value $=0, \mathrm{p}=1$, and males and females had the same value for Cockroft, notwithstanding the significant difference of weight and creatininemia; therefore, the equality of the variable age could be the basis for the equality of the Cockroft values. This signifies that the evaluation of the creatinine clearance based on the Cockroft formula could be strongly influenced by the size of the variable age, a suitable hypothesis, taking into account the relevance of age on the organic functions. This was tested by a statistic model, using random data by Minitab18, based on the mean and standard deviation of the actual data of age, weight, and creatininemia for males and females. The model resulted in the following data: males, age $54.12 \pm 13.86$, weight $76.93 \pm 10.33$, creatininemia 10.14 \pm 3.41 ; females, age 57.9 \pm 12.25 , weight $61.29 \pm 9.71$, creatininemia $9.11 \pm 2.36$. The first component of the Cockroft formula, (40 - age) $\mathrm{x}$ weight in $\mathrm{kg}$, for males was $6460.3 \pm 1439.9$, and in females, it was 5024.2 \pm 1008.2 , significantly differing, with $\mathrm{T}$ value $6.02, \mathrm{p}=0.000$. The second component, $72 \mathrm{x}$ creatininemia in $\mathrm{mg} / \mathrm{dl}$, resulted in $730.12 \pm 245.29$ for males and $656.03 \pm 170.11$ for females, $\mathrm{T}$ value $=1.83, \mathrm{p}=0.072$. The final ratio, giving the Cockroft value, $140-$ age $\mathrm{x}$ weight/72 $\mathrm{x}$ creatininemia, in males was $10.27 \pm 5.33$ and in females was $8.52 \pm 4.7$, $\mathrm{T}$ value $=1.88, \mathrm{p}=0.064$. This seems to confirm the assumption that age is the basis for the equality of Cockroft values because of the insignificant difference of age between the actual value of age, $T$ Value $0.07 \mathrm{p}=0,0484$ and the value of age in the model $\mathrm{T}$ value $=-1.56, \mathrm{p}=0.123$. The heavy weight of age values is also shown when applying the Cockroft formula and modifying the difference of ages: assuming an unmodified age for males and an increased age for females $(+15 \%) 64.5 \pm 15.04$, the final Cockroft value for females is $7.58 \pm 2.17$ significantly differing from that of males, $\mathrm{T}$ value $=2.19, \mathrm{p}=0.032$. Therefore, taking into account the relevance of age on the Cockroft formula, it seems suitable to use it when it could be useful to have an estimate of creatinine clearance related to age. A further comparison was performed in males and females, comparing the percentage differences between the estimated clearance by Cockroft and the measured $\mathrm{CtCl}$. The result was $16.88 \pm 31.89 \%$ for males and $25.2 \pm 41.6 \%$ for females: the Cockroft formula overestimated the clearance with respect to the measured $\mathrm{CtCl}$ in males and in females, with an insignificant difference between males and females, $\mathrm{T}$ value $=1.30, \mathrm{p}=0.197$. Notwithstanding the differences between Cockroft clearance and measured clearance, the two variables were found to be strongly correlated when regressing measured $\mathrm{CtCl} /$ min versus Cockroft clearance, for males, $\mathrm{R}$ 0.693, $\mathrm{R}^{2} 0.48, \mathrm{p}=0.0012$, and for females, $\mathrm{R} 0.406, \mathrm{R}^{2} 0.65, \mathrm{p}=0.0325$. The degree of correlation by the regressions is clearly represented by the difference between the predicted items and the actual items: their statistical comparison for males and females resulted in $\mathrm{T}$ value $=0, \mathrm{p}=1$, that is to say, that predicted items and actual items fully corresponded, as also shown by the very low values of residuals of regressions, $8.9 \times e^{-17}$ for males and $1.6 \mathrm{x}$ 
$e^{-16}$ for females.

The correlations

Each table of correlation reports in the title the basal variable, the variable with which the listed variables were correlated. The table of the correlations is divided into four partitions: correlated variables, $\mathrm{T}$ value, $\mathrm{p}$ values, and scores. This last is an added variable, representing a score of the correlation. This value was introduced to convert the $\mathrm{p}$ values into numerical sizes, suitable for magnifying the degree of correlations. This allows us to statistically compare by a $\mathrm{T}$ test the efficacy of the correlations according to each gender and between males and females. The scores were attributed according to an arbitrary scale: $\mathrm{p}$ value $=0.000$, score $=7, \mathrm{p}$ value lower than 0.009 and greater than 0.000, score $=5, \mathrm{p}$ value lower than 0.05 and greater than 0.01 , score $=3$. Scores were also used in the previously quoted paper [1] based on the same method of score attribution.

The correlations in males

The correlations concerning the male data are shown in 10 tables, from Table V to Table XIV.

\begin{tabular}{|c|c|c|c|c|}
\hline${ }^{n}$ & correlated variables & T Value & $\mathrm{P}$ & scores \\
\hline 1 & Height & -0.593 & 0.000 & 7 \\
\hline 2 & Cockroft & -0.43 & 0.003 & 5 \\
\hline 3 & Cockroft week & -0.43 & 0.003 & 5 \\
\hline 4 & dialysis volume & -0.392 & 0.008 & 5 \\
\hline 5 & dialysis volume/min & -0.392 & 0.008 & 5 \\
\hline 6 & dialysis volume $/ 100$ & -0.392 & 0.008 & 5 \\
\hline 7 & normalized creatinine clearance according to age & -1 & 0.000 & 7 \\
\hline 8 & creatinine clearance by ideal creatinine according to height, age/week & 0.045 & 0.002 & 5 \\
\hline 9 & Cockroft week/BMI & -0.448 & 0.002 & 5 \\
\hline $0^{1}$ & total excreted creatinine/BMI & -0.336 & 0.024 & 3 \\
\hline $1^{1}$ & total excreted creatinine/BSA & -0.304 & 0.042 & 3 \\
\hline & ideal excreted creatinine corrected by age/BMI & -0.717 & 0.000 & 7 \\
\hline & Ideal excreted creatinine corrected by age/BSA & -0.757 & 0.000 & 7 \\
\hline & excreted creatinine/weight & -0.371 & 0.012 & 3 \\
\hline & ideal excreted creatinine corrected by age/height & -1 & 0.000 & 7 \\
\hline & excreted creatinine by Cockroft/BMI & -0.772 & 0.000 & 7 \\
\hline & excreted creatinine by Cockroft/BSA & -0.704 & 0.000 & 7 \\
\hline & BSA & 0.382 & 0.01 & 3 \\
\hline & ideal creatinine according to height corrected on weight & -0.637 & 0.000 & 7 \\
\hline & delta creatinine by Cockroft minus total excreted creatinine & -0.303 & 0.043 & 3 \\
\hline & delta $\mathrm{CtCl}$ & -0.334 & 0.025 & 3 \\
\hline & delta $\mathrm{CtCl} \%$ & -1 & 0.000 & 7 \\
\hline \multirow[t]{2}{*}{$3^{2}$} & delta $\mathrm{CtCl} / \mathrm{kg}$ & -0.34 & 0.022 & 3 \\
\hline & & \multicolumn{3}{|c|}{ Scores: mean, SD: $5.17 \pm 1.7$} \\
\hline
\end{tabular}


World Journal of Research and Review (WJRR)

ISSN:2455-3956, Volume-7, Issue-3, September 2018 Pages 32-52

\begin{tabular}{|c|l|l|l|c|}
\hline \multicolumn{2}{|c|}{ Table VI A - Males - Correlation: results by Pearson correlation - basal variable: height } & T value & p & scores \\
\hline n. & correlated variables & 0.382 & $0,0.01$ & 3 \\
\hline 1 & BSA & 0.478 & 0.001 & 5 \\
\hline 2 & Cockroft & 0.478 & 0.001 & 5 \\
\hline 3 & Cockroft week & 0.327 & 0.028 & 3 \\
\hline 4 & total excreted creatinine/die & 0.485 & 0.001 & 5 \\
\hline 5 & ideal creatinine according to height corrected by weight & 0.593 & 0.000 & 7 \\
\hline 6 & delta \% & 0.412 & 0.005 & 3 \\
\hline 7 & actual creatinine clearance + delta not positive/week & 0.469 & 0.001 & 5 \\
\hline 8 & ideal creatinine according to height and weight & 0.469 & 0.001 & 5 \\
\hline 9 & Ideal creatinine according to height and weight week & Scores: mean, SD: $4.56 \pm 1.33$ \\
\cline { 2 - 5 }
\end{tabular}

\begin{tabular}{|l|l|l|l|c|}
\hline \multicolumn{2}{|l|}{ Table VI B - Males - Correlation: results by Pearson correlation - basal variable } & Value & p & scores \\
\hline \multicolumn{2}{|l|}{ correlated variables } & $0 ., 4$. & 0.006 & 5 \\
\hline 10 & creatinine clearance by ideal creatinine according to height and age/week & 0.299 & 0.046 & 5 \\
\hline 11 & not corrected creatinine clearance/BMI & 0.519 & 0.000 & 7 \\
\hline 12 & Cockroft week/BMI & 0.395 & 0.007 & 5 \\
\hline 13 & total excreted creatinine/BMI & 0.616 & 0.000 & 7 \\
\hline 14 & ideal excreted creatinine corrected by age/BMI & 0.404 & 0.006 & 5 \\
\hline 15 & ideal excreted creatinine corrected by age/BSA & 0.593 & 0.000 & 7 \\
\hline 16 & ideal excreted creatinine corrected by age/height & 0.311 & 0.038 & 3 \\
\hline 17 & total excreted creatinine/creatininemia & 0.581 & 0.000 & 7 \\
\hline 18 & excreted creatinine by Cockroft/BMI & 0.327 & 0.029 & 3 \\
\hline 19 & excreted creatinine by Cockroft/BSA & Scores: mean, SD: $5.4 \pm 1.58$ \\
\cline { 2 - 5 } & & & \\
\hline
\end{tabular}

\begin{tabular}{|l|l|l|l|l|}
\hline \multicolumn{2}{|l|}{ Table VII - Males Correlation results by Pearson correlation: basal variable: weight } \\
\hline $\mathrm{n}$ & correlated variables & T Value & $\mathrm{p}$ & \multicolumn{2}{|c|}{ scores } \\
\hline 1 & BSA & 0.694 & 0 & 7 \\
\hline 2 & creatininemia & 0.385 & 0.009 & 5 \\
\hline 3 & total excreted creatinine/die & 0.441 & 0.002 & 5 \\
\hline \multicolumn{7}{|l|}{ Table VII - Males Correlation results by Pearson correlation: basal variable: weight - following data } \\
\hline 4 & ideal excreted creatinine according to weight & 1 & 0 & 7 \\
\hline 5 & ideal creatinine according to height corrected by weight & 0.775 & 0 & 7 \\
\hline 6 & ideal excreted creatinine corrected by age/BSA & 0.593 & 0 & 7 \\
\hline
\end{tabular}


45 Males and 94 Females Undergoing Chronic Peritoneal Dialysis: Comparison and Correlation of Their Dialytic Treatment and Body Composition

Table VIII - Males Correlation results by Pearson correlation: basal variable: BSA

\begin{tabular}{|c|l|l|l|l|}
\hline & & & & \\
$\mathrm{n}$ & correlated variables & Value & $\mathrm{p}$ & scores \\
\hline 1 & BMI & 0.461 & 0.001 & 5 \\
\hline 2 & ideal creatinine according to height corrected by weight & 0.537 & 0.000 & 7 \\
\hline 3 & positive delta of creatinine clearance & 0.321 & 0.031 & 3 \\
\hline \multicolumn{2}{|l}{} & \multicolumn{2}{|c|}{ scores: mean 5, SD 2 } \\
\cline { 2 - 5 }
\end{tabular}

\begin{tabular}{|l|l|l|l|l|}
\hline \multicolumn{2}{|l|}{ Table IX - Males Correlation results by Pearson correlation: basal variable: BMI } & \multicolumn{2}{l|}{} & \multicolumn{2}{l|}{ scores } \\
\hline $\mathrm{n}$ & correlated variables & Value & $\mathrm{p}$ & 5 \\
\hline & & 0.388 & 0.008 & \\
\hline 1 & creatininemia & & & 3 \\
\hline 2 & total creatinine clearance week & -0.301 & 0.044 & 7 \\
\hline 3 & ideal excreted creatinine according to weight & 0.596 & 0 & 3 \\
\hline 4 & ideal creatinine according to height corrected by weight & 0.355 & 0.017 & 3 \\
\hline 5 & delta of creatinine by Cockroft - total excreted creatinine & 0.338 & 0.023 & 3 \\
\hline 6 & no corrected creatinine clearance /BSA & -0.359 & 0.016 & 7 \\
\hline 7 & no corrected creatinine clearance /BMI & -0.567 & 0 & 7 \\
\hline 8 & Cockroft week/BMI & -0.548 & 0 & 7 \\
\hline 9 & ideal excreted creatinine corrected by age/BMI & -0.506 & 0 & 3 \\
\hline 10 & excreted creatinine by Cockroft/BMI & -0.357 & 0.016 & Scores, mean, SD: 4.8.199 \\
\hline
\end{tabular}

\begin{tabular}{|c|c|c|c|c|}
\hline $\mathrm{n}$ & correlated variables & Value & $\mathrm{P}$ & Scores \\
\hline 1 & Cockroft & -0.579 & 0.000 & 7 \\
\hline 2 & total creatinine clearance week & -0.565 & 0.000 & 7 \\
\hline 3 & ideal excreted creatinine according to weight & 0.385 & 0.009 & 5 \\
\hline 4 & ideal creatinine according to height corrected by weight & 0.38 & 0.01 & 3 \\
\hline 5 & positive delta of creatinine clearance $/ \mathrm{kg}$ & -0.295 & 0.049 & 3 \\
\hline 6 & creatinine clearance by ideal creatinine according to height and age/week & -0.649 & 0.000 & 7 \\
\hline 7 & no corrected creatinine clearance/BMI & -0.576 & 0.000 & 7 \\
\hline 8 & Cockroft week/BMI & -0.654 & 0.000 & 7 \\
\hline 9 & ideal excreted creatinine corrected by age/BSA & 0.387 & 0.009 & 5 \\
\hline 10 & excreted creatinine by Cockroft/BSA & 0.365 & 0.014 & 3 \\
\hline \multicolumn{5}{|c|}{ Scores: mean, SD: $5.4 \pm 1.84$} \\
\hline
\end{tabular}

\begin{tabular}{|c|l|c|c|c|}
\hline \multicolumn{2}{|c|}{ Table XI - Males Correlation results by Pearson correlation: basal variable: Cockroft } & & & \\
\hline & & Value & p & scores \\
\hline $\mathrm{n}$ & correlated variables & 0.321 & 0.032 & 3 \\
\hline & & dialysis volume & & 3 \\
\hline
\end{tabular}


World Journal of Research and Review (WJRR) ISSN:2455-3956, Volume-7, Issue-3, September 2018 Pages 32-52

\begin{tabular}{|c|c|c|c|c|}
\hline 2 & dialysis volume/min & 0.321 & 0.032 & 3 \\
\hline 3 & dialysis volume/100 & 0.321 & 0.032 & 3 \\
\hline 4 & total creatinine clearance week & 0.634 & 0.000 & 7 \\
\hline 5 & normalized creatinine clearance according to age & 0.43 & 0.003 & 5 \\
\hline 6 & ideal creatinine according to height corrected by weight & 0.468 & 0.001 & 5 \\
\hline \multicolumn{5}{|c|}{ Table XI - Males Correlation results by Pearson correlation: basal variable: Cockroft - following data } \\
\hline 7 & positive delta creatinine clearance & 0.521 & 0.000 & 7 \\
\hline 8 & positive delta creatinine clearance $/ \mathrm{kg}$ & 0.485 & 0.001 & 5 \\
\hline 9 & actual creatinine clearance + delta no positive week & 0.92 & 0.000 & 7 \\
\hline 10 & actual creatinine clearance + delta positive week & 0.652 & 0.000 & 7 \\
\hline 11 & creatinine clearance by ideal creatinine according to weight and age & 0.961 & 0.000 & 7 \\
\hline 12 & no corrected creatinine clearance/BSA & 0.574 & 0.000 & 7 \\
\hline 13 & no corrected creatinine clearance/BMI & 0.568 & 0.000 & 7 \\
\hline 14 & Cockroft week/BMI & 0.857 & 0.000 & 7 \\
\hline 15 & ideal excreted creatinine corrected by age/BMI & 0.449 & 0.002 & 5 \\
\hline 16 & ideal excreted creatinine corrected by age/BSA & 0.42 & 0.004 & 5 \\
\hline 17 & ideal excreted creatinine corrected by age/height & 0.43 & 0.003 & 5 \\
\hline 18 & total excreted creatinine/creatininemia & 0.679 & 0.000 & 7 \\
\hline 19 & excreted creatinine by Cockroft/BSA & 0.454 & 0.002 & 5 \\
\hline & & \multicolumn{3}{|c|}{ Scores: mean, SD: $5.63 \pm 1.5$} \\
\hline \multicolumn{5}{|c|}{ Table XII - Males Correlation results by Pearson correlation: basal variable: dialysis volume } \\
\hline $\mathrm{n}$ & correlated variables & Value & $\mathrm{P}$ & scores \\
\hline 1 & normalized creatinine clearance according to age & 0.392 & 0.008 & 5 \\
\hline 2 & delta dialysis clearance & 0.36 & 0.015 & 3 \\
\hline 3 & delta $\%$ & 0.392 & 0.008 & 5 \\
\hline 4 & Delta creatinine clearance $/ \mathrm{kg}$ & 0.311 & 0.037 & 3 \\
\hline 5 & creatinine clearance by ideal creatinine according to height and age/week & 0.323 & 0.03 & 3 \\
\hline 6 & ideal excreted creatinine corrected by age/BSA & 0.389 & 0.008 & 5 \\
\hline 7 & ideal excreted creatinine corrected by age/height & 0.392 & 0.008 & 5 \\
\hline \multicolumn{5}{|c|}{ Table XII - Males Correlation results by Pearson correlation: basal variable: dialysis volume - following data } \\
\hline 8 & excreted creatinine by Cockroft/BMI & 0.384 & 0.009 & 5 \\
\hline 9 & excreted creatinine by Cockroft/BSA & 0.467 & 0.001 & 5 \\
\hline & & \multicolumn{3}{|c|}{ Scores: mean, SD: $4.33 \pm 1$} \\
\hline
\end{tabular}

\begin{tabular}{|l|l|c|c|c|}
\hline \multicolumn{2}{|l|}{ Table XIII - Males Correlation results by Pearson correlation: basal variable: total creatinine clearance week } \\
\hline $\mathrm{n}$ & correlated variables & Value & $\mathrm{P}$ & scores \\
\hline 1 & delta creatinine by Cockroft - total excreted creatinine & -0.537 & 0.000 & 7 \\
\hline 2 & delta creatinine clearance & -0.606 & 0.000 & 7 \\
\hline 3 & delta creatinine clearance/kg & -0.64 & 0.000 & 7 \\
\hline 4 & positive delta creatinine clearance/kg & 0.309 & 0039 & 3 \\
\hline 5 & actual creatinine clearance + delta no positive week & 0.682 & 0.000 & 7 \\
\hline 6 & actual creatinine clearance + delta positive week & 0.999 & 0.000 & 7 \\
\hline 7 & creatinine clearance by ideal creatinine according to weight and age week & 0.719 & 0.000 & 7 \\
\hline 8 & creatinine clearance by ideal creatinine according to height and age week & 0.678 & 0.000 & 7 \\
\hline 9 & no corrected creatinine clearance/BSA & 0.985 & 0.000 & 7 \\
\hline 10 & no corrected creatinine clearance/BMI & 0.944 & 0.000 & 7 \\
\hline 11 & total excreted creatinine/BMI & 0.656 & 0.000 & 7 \\
\hline 12 & total excreted creatinine/BSA & 0.611 & 0.000 & 7 \\
\hline 13 & excreted creatinine/weight & 0.661 & 0.000 & 7 \\
\hline
\end{tabular}


45 Males and 94 Females Undergoing Chronic Peritoneal Dialysis: Comparison and Correlation of Their Dialytic Treatment and Body Composition

14 total excreted creatinine/ ideal excreted creatinine by weight

0.686

\begin{tabular}{l|l}
0.000 & 7
\end{tabular}

Scores: mean, SD: $6.71,0.07$

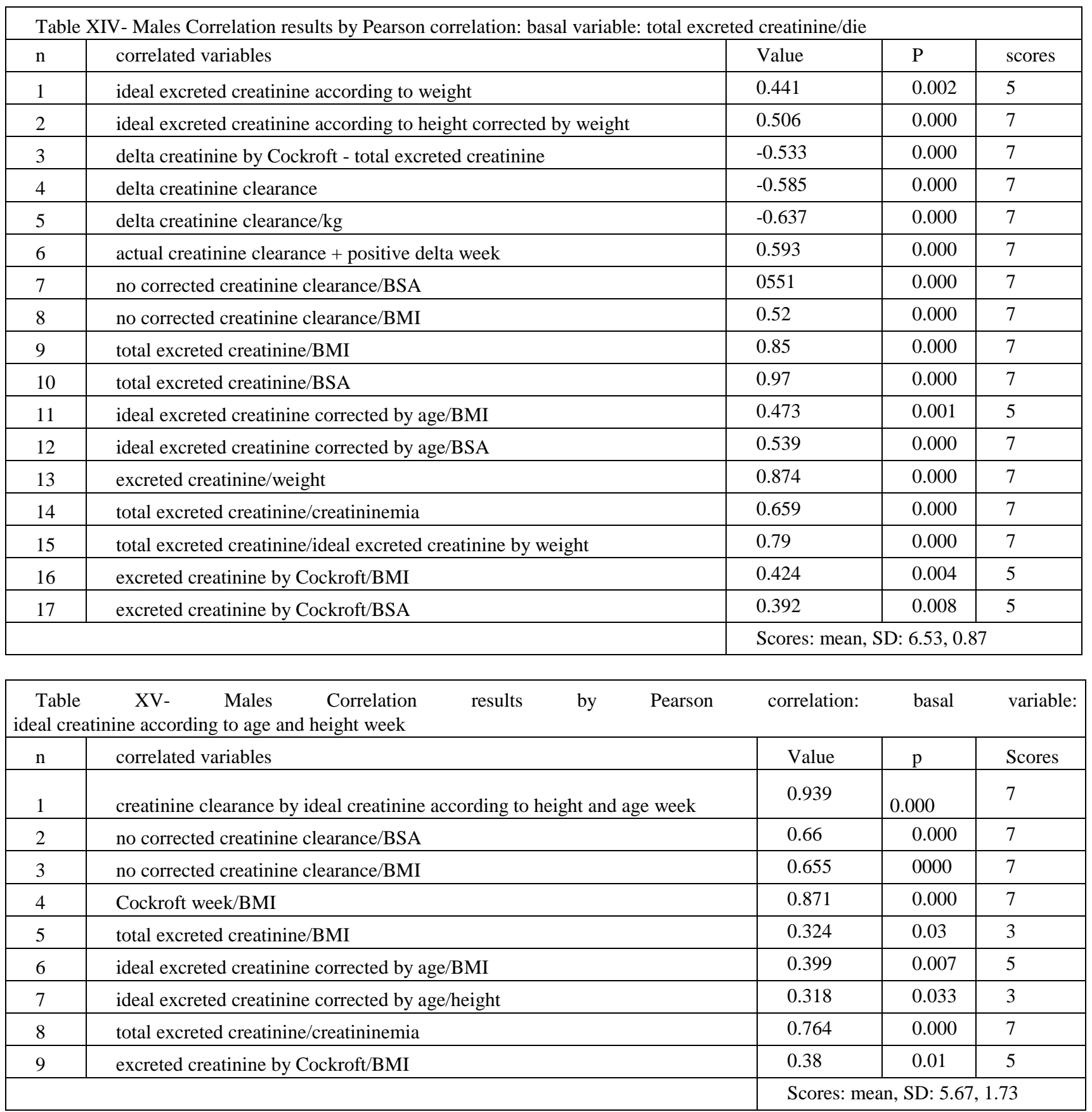

11 basal variables were correlated with 29 variables by the Pearson correlation. This generated 139 significant correlations in males. Each table reports the average and standard deviation of scores. The ratio mean of the scores/standard deviation measures the magnitude of the dispersion of the scores, that is to say, the width of the range of the significance of the correlations linked to each of 11 basal variable. The evaluation of this range reveals the relevance of the correlations for each basal variable. This may be calculated by the formula, range $=[($ mean of the scores $+($ standard deviation $\mathrm{x} 2)]$ minus $[($ mean of the scores - (standard deviation $\mathrm{x}$ 2)]. The results of this calculation are reported in the following table, Table XVI. Ranges are shown for decreasing values side by side with the corresponding basal variable, and the coefficient of variation (standard deviation/mean), as mentioned above, measures the dispersion of the items of a variable. It has to be noted that the coefficients of variations are decreasing in parallel with ranges, but with irregular progress. A series of linear regressions was performed to study the relationships within the ranges of scores, the coefficients of variation and the numerousness of correlations. The first regression demonstrated that, the wider the range was, the wider the dispersion of the data was. The second linear regression states that the ranges of the score normalized by the number of items of each correlation are correlated with the coefficients of 
World Journal of Research and Review (WJRR)

ISSN:2455-3956, Volume-7, Issue-3, September 2018 Pages 32-52

variation, that is to say, the greater the number of correlations for each basal variable, the greater the dispersions of the scores, i.e., the basal variables attaining a great number of correlations have correlations according to very different degrees of positive significance.

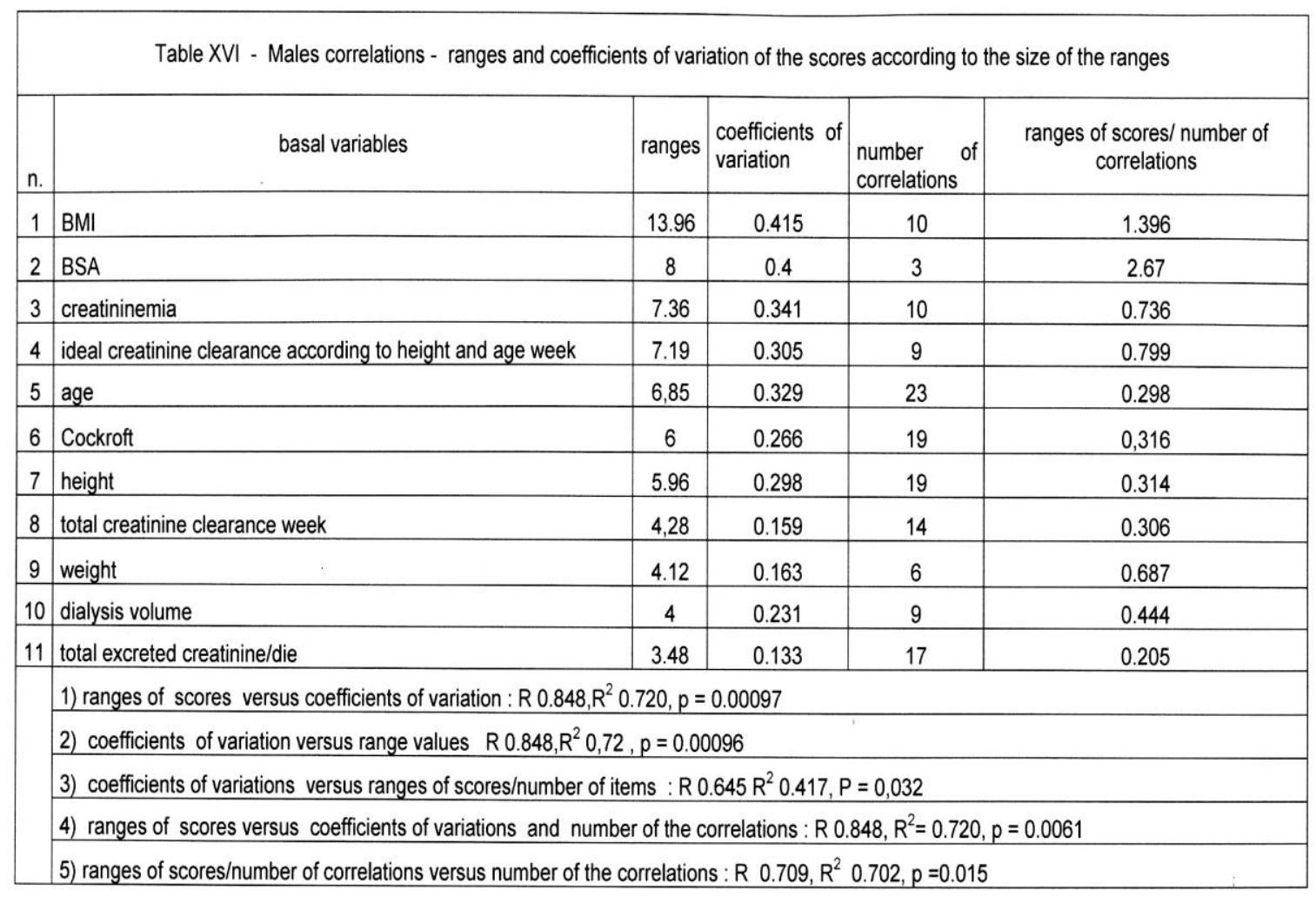

The third regression shows that the ranges of the scores are linked with a consistent dispersion of data and are dependent by the numerousness of the correlations. The fourth regression returns an expected result, that is, the ranges of the scores/normalized on the number of the correlations are dependent on the numerousness of the correlations and not on the size of the scores ranges: regressing the ranges of scores/number of the correlations versus ranges of scores results in $\mathrm{R} 0.543, \mathrm{R}^{2}$ $0.295, p=0.084$. The fourth is a polynomial regression, ranges of the scores versus coefficients of variations and number of correlations: $\mathrm{R} 0.848, \mathrm{R}^{2}=0.720, \mathrm{p}=0.0061$ : the results of the regressions are the same as those in the first regression but with a decreased significance, 0.0061 versus 0.00097 . An analysis of the regression shows that this decreased significance is based on different significances of the predicting variables: high significance for the coefficient of variation, 0.00218 , and no significance for the number of correlations, 0.88 . Therefore, the significance of regression decreased due to a negative mathematical effect of the second predicting variable. The fifth regression is between the number of correlations and the ranges of the scores indexed on the number of correlations: notwithstanding the numerical link existing between the first and the second variable, indexed on the first, the regression showed a moderate significance; this is probably due to the different distribution of the items between the variables, a difference evaluable by the difference of their coefficients of variation, 0.334 versus 0.296 , with a percentage difference greater than $10 \%, 11.38 \%$. Final observations are as follows: a) BMI and BSA generated the greatest ranges and the greatest coefficients of variation; $b$ ) the lowest respective values are from total excreted creatinine/die; and c) the high significance of correspondence between the ranges of the scores and the consistent coefficients of variation shows that the ranges of the scores likely have a high variance of distribution, that is, 8.57 for the coefficient of variation, 38.7 for the number of correlations and 0.528 for the ranges of scores/number of correlations: the number of the correlations have the greatest variance. For a better understanding of the significance of the numbers above, two examples are shown: the following series of numbers $0.5 ; 0.7 ; 0.9 ; 1.1 ; 1.3 ; 1.5 ; 1.7 ; 1.9 ; 2.1 ; 2.3 ; 2.5$ has a fixed factor of increase, 0.2 , and its variance is 0.440 , whereas the series $3 ; 5.7 ; 2.11 .81 ; 24.57 ; 8 ; 9 ; 13$, based on random numbers has a variance of 657 : in practical terms, the greater the diversity of the items values in a variable, the greater the variance, as pointed out in the presented correlations.

The correlations in females

The correlations concerning the female data are shown in 10 tables, from Table XVII to Table XXXI. For males, each table reports in the title the basal variable, the variable correlated with the remaining variables. In the last column of each correlation are the values of the scores. 


\begin{tabular}{|c|c|c|c|c|}
\hline \multicolumn{5}{|c|}{ Table XVII - Females Correlation results by Pearson correlation: basal variable: age } \\
\hline $\mathrm{n}$ & correlated variables & T value & $\mathrm{p}$ & scores \\
\hline 1 & Height & -0.209 & 0.043 & 3 \\
\hline 2 & BSA & -0.203 & 0.049 & 3 \\
\hline 3 & Creatininemia & -0.343 & 0.001 & 5 \\
\hline 4 & Cockroft & -0.218 & 0.035 & 3 \\
\hline 5 & total creatinine clearance week & 0.286 & 0.005 & 5 \\
\hline 6 & normalized creatinine clearance according to age & -1 & 0.000 & 7 \\
\hline 7 & total excreted creatinine/die & -0.258 & 0.012 & 3 \\
\hline 8 & ideal creatinine according to height corrected by weight & -0.688 & 0.000 & 7 \\
\hline 9 & delta creatinine by Cockroft - total excreted creatinine & -0.476 & 0.000 & 7 \\
\hline 10 & delta creatinine clearance & -0.361 & 0.000 & 7 \\
\hline 11 & delta $\%$ & -1 & 0.000 & 7 \\
\hline 12 & delta creatinine clearance/kg & -0.338 & 0.001 & 5 \\
\hline 13 & positive delta creatinine clearance $/ \mathrm{kg}$ & -0.287 & 0.005 & 5 \\
\hline 14 & actual creatinine clearance + positive delta week & 0.255 & 0.013 & 3 \\
\hline \multicolumn{5}{|c|}{ Table XVII - Females Correlation results by Pearson correlation: basal variable: age - following data } \\
\hline 15 & no corrected creatinine clearance/BSA & 0.336 & 0.001 & 5 \\
\hline 16 & no corrected creatinine clearance/BMI & 0.296 & 0.004 & 5 \\
\hline 17 & ideal excreted creatinine corrected by age/BMI & -0.854 & 0.000 & 7 \\
\hline 18 & ideal excreted creatinine corrected by age/BSA & -0.859 & 0.000 & 7 \\
\hline 19 & ideal excreted creatinine corrected by age/height & -1 & 0.000 & 7 \\
\hline 20 & total excreted creatinine/ideal excreted creatinine by weight & 0.271 & 0.008 & 5 \\
\hline 21 & excreted creatinine by Cockroft/BMI & -0.794 & 0.000 & 7 \\
\hline 22 & excreted creatinine by Cockroft/BSA & -0.783 & 0.000 & 7 \\
\hline & & \multicolumn{3}{|c|}{ Scores, mean, SD: 5.45, 1.63} \\
\hline
\end{tabular}

\begin{tabular}{|l|l|l|l|l|}
\hline \multicolumn{2}{|l}{ Table XVIII - Females Correlation results by Pearson correlation: basal variable: height } \\
\hline $\mathrm{n}$ & correlated variables & T value & $\mathrm{p}$ & $\mathrm{s}$ \\
\hline 1 & Weight & 0.466 & 0.000 & 7 \\
\hline 2 & BSA & 0.741 & 0.000 & 7 \\
\hline 3 & Cockroft & 0.212 & 0.04 & 3 \\
\hline 4 & normalized creatinine clearance according to age & 0.209 & 0.043 & 3 \\
\hline 5 & ideal creatinine according to height corrected by weight & 0.474 & 0.000 & 7 \\
\hline 6 & delta creatinine by Cockroft - total excreted creatinine & 0.211 & 0.042 & 3 \\
\hline 7 & delta \% & 0.209 & 0.043 & 3 \\
\hline 8 & no corrected creatinine clearance/BSA & -0.338 & 0.001 & 5 \\
\hline 9 & Cockroft week/BMI & 0.265 & 0.01 & 3 \\
\hline 10 & total excreted creatinine/BMI & 0.273 & 0.008 & 5 \\
\hline 11 & excreted creatinine corrected by age/BMI & 0.682 & 0.000 & 7 \\
\hline 12 & excreted creatinine corrected by age/BSA & 0.25 & 0.015 & 3 \\
\hline 13 & ideal excreted creatinine corrected by age/height & 0.209 & 0.043 & 3 \\
\hline 14 & excreted creatinine by Cockroft/BMI & 0.633 & 0.000 & 7 \\
\hline & & & Scores, mean, SD: 4.71, \\
\hline
\end{tabular}


World Journal of Research and Review (WJRR)

ISSN:2455-3956, Volume-7, Issue-3, September 2018 Pages 32-52

\begin{tabular}{|c|c|c|c|c|}
\hline \multicolumn{5}{|c|}{ Table XIX - Females Correlation results by Pearson correlation: basal variable: weight } \\
\hline $\mathrm{n}$ & correlated variables & $\begin{array}{c}\mathrm{T} \\
\text { value } \\
\end{array}$ & $\mathrm{P}$ & \begin{tabular}{ll}
\multicolumn{1}{|c}{ score } \\
$\mathrm{s}$
\end{tabular} \\
\hline 1 & BSA & 0.939 & $0^{0.00}$ & 7 \\
\hline 2 & BMI & 0.816 & $0^{0.00}$ & 7 \\
\hline 3 & Creatininemia & 0.233 & $4^{0.02}$ & 3 \\
\hline 4 & Cockroft & 0.413 & $0^{0.00}$ & 7 \\
\hline 5 & ideal excreted creatinine according to weight & 1 & $0^{0.00}$ & 7 \\
\hline 6 & ideal creatinine according to height corrected & 0.822 & $0^{0.00}$ & 7 \\
\hline 7 & delta creatinine by Cockroft - total excreted creatinine & 0.48 & $0^{0.00}$ & 7 \\
\hline 8 & delta creatinine clearance & 0.379 & $0^{0.00}$ & 7 \\
\hline 9 & delta creatinine clearance $/ \mathrm{kg}$ & 0.218 & $5^{0.03}$ & 3 \\
\hline \multicolumn{5}{|c|}{ Table XIX - Females Correlation results by Pearson correlation: basal variable: weight - following data } \\
\hline 10 & positive delta of creatinine clearance & 0.366 & $0^{0.00}$ & 7 \\
\hline 11 & creatinine clearance by ideal creatinine according to weight and age & 0.409 & $0^{0.00}$ & 7 \\
\hline 12 & creatinine clearance by ideal creatinine according to weight and age/week & 0.409 & $0^{0.00}$ & 7 \\
\hline 13 & no corrected creatinine clearance/BSA & -0.343 & $1^{0.00}$ & 5 \\
\hline 14 & ideal excreted creatinine corrected by age/BMI & 0.38 & $0^{0.00}$ & 7 \\
\hline 15 & ideal excreted creatinine corrected by age/BSA & 0.613 & $0^{0.00}$ & 7 \\
\hline 16 & excreted creatinine by Cockroft /BMI & 0.379 & $0^{0.00}$ & 7 \\
\hline 17 & excreted creatinine by Cockroft /BSA & 0.572 & $0^{0.00}$ & 7 \\
\hline
\end{tabular}

\begin{tabular}{|c|c|c|c|c|}
\hline $\mathrm{n}$ & correlated variables & $\begin{array}{c}\mathrm{T} \\
\text { value }\end{array}$ & $\mathrm{P}$ & scores \\
\hline 1 & BMI & 0.57 & 0.000 & 7 \\
\hline 2 & Creatininemia & 0.249 & 0.016 & 3 \\
\hline 3 & Cockroft & 0.397 & 0.000 & 7 \\
\hline 4 & normalized creatinine clearance according to age & 0.203 & 0.049 & 3 \\
\hline 5 & ideal creatinine according to height corrected by weight & 0.807 & 0.000 & 7 \\
\hline 6 & delta creatinine clearance & 0.354 & 0.000 & 7 \\
\hline 7 & delta $\%$ & 0.203 & 0.049 & 3 \\
\hline 8 & delta creatinine clearance/kg & 0.207 & 0.045 & 3 \\
\hline 9 & positive delta creatinine clearance & 0.35 & 0.001 & 5 \\
\hline 10 & creatinine clearance by ideal creatinine according to weight and age & 0.387 & 0.000 & 7 \\
\hline 11 & creatinine clearance by ideal creatinine according to weight and age/week & 0.387 & 0.000 & 7 \\
\hline 12 & no corrected creatinine clearance/BSA & -0.391 & 0.000 & 7 \\
\hline 13 & no corrected creatinine clearance/BMI & -0.359 & 0.000 & 7 \\
\hline 14 & ideal excreted creatinine corrected by age/BMI & 0.552 & 0.000 & 7 \\
\hline 15 & ideal excreted creatinine corrected by age/BSA & 0.562 & 0.000 & 7 \\
\hline 16 & ideal excreted creatinine corrected by age/height & 0.203 & 0.049 & 3 \\
\hline
\end{tabular}




\begin{tabular}{|l|l|l|l|l|}
\cline { 2 - 5 } 17 & total excreted creatinine/ideal excreted creatinine by weight & -0.233 & 0.024 & 3 \\
\hline 18 & excreted creatinine by Cockroft/BMI & 0.534 & 0.000 & 7 \\
\hline 19 & excreted creatinine by Cockroft/BSA & 0.533 & 0.000 & 7 \\
\hline
\end{tabular}

\begin{tabular}{|l|l|l|l|l|}
\hline \multicolumn{2}{|l|}{ Table XXI - Females Correlation results by Pearson correlation: basal variable: BMI } & T value & P & scores \\
\hline N & correlated variables & 0.309 & 0.002 & 5 \\
\hline 1 & Cockroft & 0.816 & 0.000 & 7 \\
\hline 2 & ideal excreted creatinine according to weight & 0.599 & 0.000 & 7 \\
\hline 3 & ideal creatinine according to height corrected by weight & 0.395 & 0.000 & 7 \\
\hline 4 & delta creatinine by Cockroft - total excreted creatinine & 0.308 & 0.003 & 5 \\
\hline 5 & delta creatinine clearance & 0.283 & 0.006 & 5 \\
\hline 6 & positive delta creatinine clearance & 0.313 & 0.002 & 5 \\
\hline 7 & creatinine clearance by ideal creatinine according to weight and age & 0.313 & 0.002 & 5 \\
\hline 8 & creatinine clearance by ideal creatinine according to height and age/week & & \\
\hline Table XXI - Females Correlation results by Pearson correlation: basal variable: BMI - following data & -0.396 & 0.000 & 7 \\
\hline 9 & no corrected creatinine clearance/BMI & -0.248 & 0.016 & 3 \\
\hline 10 & total excreted creatinine/BMI & 0.508 & 0.000 & 7 \\
\hline 11 & ideal excreted creatinine corrected by age/BSA & -0.234 & 0.023 & 3 \\
\hline 12 & excreted creatinine/weight & -0.245 & 0.017 & 3 \\
\hline 13 & total excreted creatinine/ideal excreted creatinine by weight & 0.464 & 0.000 & 7 \\
\hline 14 & excreted creatinine by Cockroft/BSA & Scores, mean, SD: $5.43,1.6$ \\
\hline
\end{tabular}

\begin{tabular}{|l|l|c|c|c|}
\hline \multicolumn{2}{|l|}{ Table XXII A - Females Correlation results by Pearson correlation: basal variable: creatininemia } \\
\hline $\mathrm{n}$ & correlated variables & T value & $\mathrm{p}$ & $\mathrm{s}$ \\
\hline 1 & Cockroft & 0.631 & 0.000 & $\mathbf{7}$ \\
\hline 2 & dialysis volume & 0.317 & 0.002 & $\mathbf{5}$ \\
\hline 3 & dialysis volume/min & 0.317 & 0.002 & $\mathbf{5}$ \\
\hline 4 & dialysis volume/100 & 0.317 & 0.002 & $\mathbf{5}$ \\
\hline 5 & total creatinine clearance/week & -0.69 & 0.000 & $\mathbf{7}$ \\
\hline 6 & normalized creatinine clearance according to age & 0.343 & 0.001 & $\mathbf{5}$ \\
\hline 7 & total excreted creatinine/die & 0.262 & 0.011 & $\mathbf{3}$ \\
\hline 8 & ideal excreted creatinine according to weight & 0.233 & 0.024 & $\mathbf{3}$ \\
\hline 9 & ideal creatinine according to height corrected by weight & 0.34 & 0.001 & $\mathbf{5}$ \\
\hline 10 & delta $\%$ & 0.343 & 0.001 & $\mathbf{5}$ \\
\hline 11 & delta creatinine clearance/kg & -0.229 & 0.026 & $\mathbf{3}$ \\
\hline 12 & positive delta of creatinine clearance & -0.325 & 0.001 & $\mathbf{5}$ \\
\hline 13 & positive delta of creatinine clearance/kg & -0.409 & 0.000 & $\mathbf{7}$ \\
\hline 14 & actual creatinine clearance + not positive delta week & -0.658 & 0.000 & $\mathbf{7}$ \\
\hline
\end{tabular}

\begin{tabular}{|l|l|l|l|l|}
\hline \multicolumn{2}{|c|}{ Table XXII B - Females Correlation results by Pearson correlation: basal variable: creatininemia } \\
\hline $\mathrm{n}$ & correlated variables & T value & P & scores \\
\hline 15 & actual creatinine clearance + positive delta week & -0.71 & 0.000 & 7 \\
\hline 16 & creatinine clearance by ideal creatinine according to weight and age & -0.679 & 0.000 & 7 \\
\hline 17 & creatinine clearance by ideal creatinine according to height and age & -0679 & 0.000 & 7 \\
\hline 18 & creatinine clearance by ideal creatinine according to height and age week & -0.79 & 0.000 & 7 \\
\hline 19 & no corrected creatinine clearance/BMI & -0.687 & 0.000 & 7 \\
\hline
\end{tabular}


World Journal of Research and Review (WJRR)

ISSN:2455-3956, Volume-7, Issue-3, September 2018 Pages 32-52

\begin{tabular}{|l|l|l|l|l|}
\cline { 2 - 5 } 20 & Cockroft week/BMI & -0.752 & 0.000 & 7 \\
\hline 21 & excreted creatinine/BSA & 0.262 & 0.011 & 3 \\
\hline 22 & ideal excreted creatinine corrected by age/BMI & 0.331 & 0.001 & 5 \\
\hline 23 & ideal excreted creatinine corrected by age/BSA & 0.365 & 0.000 & 7 \\
\hline 24 & excreted creatinine/weight & 0.216 & 0.036 & 3 \\
\hline 25 & ideal excreted creatinine corrected on age/height & 0.343 & 0.001 & 5 \\
\hline 26 & total excreted creatinine/creatininemia & -0.422 & 0.000 & 7 \\
\hline 27 & excreted creatinine by Cockroft/BMI & 0.281 & 0.006 & 5 \\
\hline 28 & excreted creatinine by Cockroft/BSA & 0.305 & 0.003 & 5 \\
\hline
\end{tabular}

\begin{tabular}{|l|l|l|l|c|}
\hline \multicolumn{2}{|l|}{ Table XXIII - Females Correlation results by Pearson correlation: basal variable: Cockroft } & \multicolumn{2}{l|}{ score } \\
\hline $\mathrm{n}$ & correlated variables & T value & $\mathrm{p}$ & $\mathrm{s}$ \\
\hline 1 & dialysis volume & -0.346 & 0.001 & 5 \\
\hline 2 & total creatinine clearance week & 0.478 & 0.000 & 7 \\
\hline 3 & normalized creatinine clearance according to age & 0.218 & 0.035 & 3 \\
\hline 4 & ideal excreted creatinine according to weight & 0.413 & 0.000 & 7 \\
\hline 5 & ideal creatinine according to height corrected by weight & 0.458 & 0.000 & 7 \\
\hline 6 & delta creatinine by Cockroft - total excreted creatinine & 0.387 & 0.000 & 7 \\
\hline 7 & delta $\%$ & 0.218 & 0.035 & 3 \\
\hline 8 & delta creatinine clearance/kg & 0.392 & 0.000 & 7 \\
\hline 9 & positive delta creatinine clearance/kg & 0.514 & 0.000 & 7 \\
\hline 10 & actual creatinine clearance + delta no positive week & 0.703 & 0.000 & 7 \\
\hline 11 & actual creatinine clearance + delta positive week & 0.521 & 0.000 & 7 \\
\hline
\end{tabular}

\begin{tabular}{|l|l|c|c|c|}
\hline \multicolumn{2}{|l|}{ Table XXIV - Females Correlation results by Pearson correlation: basal variable: dialysis volume } & \multicolumn{3}{l|}{ score } \\
\hline $\mathrm{n}$ & correlated variables & T value & $\mathrm{P}$ & $\mathrm{s}$ \\
\hline 1 & total creatinine clearance week & -0.344 & 0.001 & 5 \\
\hline 2 & total excreted creatinine/die & 0.314 & 0.002 & 5 \\
\hline 3 & actual creatinine clearance + not positive delta week & -0.328 & 0.001 & 5 \\
\hline 4 & actual creatinine clearance + positive delta week & -0.354 & 0.000 & 7 \\
\hline 5 & creatinine clearance by ideal creatinine according to weight and age & -0.298 & 0.004 & 5 \\
\hline 6 & creatinine clearance by ideal creatinine according to height and age/week & -0.361 & 0.000 & 7 \\
\hline 7 & no corrected creatinine clearance/BSA & -0.31 & 0.002 & 5 \\
\hline 8 & no corrected creatinine clearance/BMI & -0.322 & 0.002 & 5 \\
\hline 9 & Cockroft week/BMI & -0.363 & 0.000 & 7 \\
\hline 10 & total excreted creatinine/creatininemia & -0.24 & 0.02 & 3 \\
\hline & & Scores, mean, SD: $5.4,1.26$ \\
\hline
\end{tabular}

\begin{tabular}{|l|l|c|c|c|}
\hline \multicolumn{2}{|c|}{ Table XXV-- Females - Correlation results by Pearson correlation: basal variable: total excreted creatinine/die } \\
\hline $\mathrm{n}$ & correlated variables & T Value & $\mathrm{p}$ & Scores \\
\hline 1 & Age & -0.258 & 0.012 & 3 \\
\hline 2 & Creatininemia & 0.262 & 0.000 & 7 \\
\hline 3 & dialysis volume & 0.314 & 0.011 & 3 \\
\hline 4 & dialysis volume/min & 0.314 & 0.002 & 5 \\
\hline 5 & dialysis volume/100 & 0.314 & 0.002 & 5 \\
\hline
\end{tabular}




\begin{tabular}{|l|l|l|l|l|}
\cline { 2 - 5 } & normalized creatinine clearance according to age & 0.258 & 0.012 & 3 \\
\hline 7 & delta \% & 0.258 & 0.012 & 3 \\
\hline 8 & Cockroft week/BSA & -0.212 & 0.04 & 3 \\
\hline 9 & excreted creatinine according to weight corrected by height & 0.275 & 0.007 & 5 \\
\hline 10 & excreted creatinine according to weight corrected by age/height & 0.258 & 0.000 & 7 \\
\hline
\end{tabular}

Table XXVI - Females Correlation results by Pearson correlation:

variable: clearance creatinine by ideal creatinine according to height and age/week

\begin{tabular}{|l|l|l|l|l|}
\hline \multicolumn{2}{|c|}{ variable: clearance creatinine by ideal creatinine according to height and age/week } & T value & $\mathrm{p}$ & scores \\
\hline 1 & correlated variables & 0.54 & 0.000 & 7 \\
\hline 2 & no corrected creatinine clearance/BSA & 0.907 & 0.000 & 7 \\
\hline 3 & Cockroft week/BMI & 0.548 & 0.000 & 7 \\
\hline 4 & total excreted creatinine/creatininemia & 0.283 & 0.006 & 5 \\
\hline 5 & excreted creatinine by Cockroft/BMI & 0.352 & 0.001 & 5 \\
\hline 6 & excreted creatinine by Cockroft/BSA & 0.548 & 0.000 & 7 \\
\hline 7 & total excreted creatinine/creatininemia & 0.283 & 0.006 & 5 \\
\hline 8 & excreted creatinine by Cockroft/BMI & 0.352 & 0.001 & 5 \\
\hline
\end{tabular}

\begin{tabular}{|r|l|l|l|l|}
\hline \multicolumn{2}{|c|}{ Table XXVII - Females Correlation results by Pearson correlation: basal variable: total creatinine clearance week } \\
\hline $\mathrm{n}$ & correlated variables & T value & $\mathrm{p}$ & $\mathrm{scores}$ \\
\hline 1 & Age & 0.286 & 0.005 & 5 \\
\hline 2 & Creatininemia & -0.69 & 0.000 & 7 \\
\hline 3 & Cockroft & 0.478 & 0.000 & 7 \\
\hline 4 & dialysis volume & -0.344 & 0001 & 5 \\
\hline 5 & normalized creatinine clearance according to age & -0.286 & 0.005 & 5 \\
\hline 6 & ideal creatinine according to height & -0.222 & 0.032 & 3 \\
\hline 7 & creatinine clearance by ideal creatinine according to weight and age & 0.516 & 0.0000 & 7 \\
\hline
\end{tabular}

\begin{tabular}{|l|l|l|l|l|c|}
\hline \multicolumn{2}{|c|}{ Table XXVIII. Females correlations - ranges and coefficients of variation of the scores according to the size of the range } \\
\hline $\mathrm{N}$ & basal variables & range & $\begin{array}{c}\text { ranges } \\
\text { coefficient } \\
\text { variation }\end{array}$ & $\begin{array}{c}\text { of } \\
\text { number of the } \\
\text { correlations }\end{array}$ & $\begin{array}{c}\text { scores/number } \\
\text { correlations }\end{array}$ \\
\hline 1 & Height & $\mathbf{7 . 6}$ & 0.403 & 14 & 0.543 \\
\hline 2 & BSA & 7.56 & 0.336 & 19 & 0.398 \\
\hline 3 & total excreted creatinine/die & 6.6 & 0.412 & 10 & 0.66 \\
\hline 4 & Cockroft 1 & 6.56 & 0.269 & 11 & 0.596 \\
\hline 5 & Cockroft 2 & 5.64 & 0.235 & 10 & 0.564 \\
\hline 5 & Age & $\mathbf{6 . 5 2}$ & 0.248 & 22 & 0.296 \\
\hline 6 & BMI & 6.4 & 0.295 & 14 & 0.457 \\
\hline 7 & total creatinine clearance week & 6.04 & 0.271 & 7 & 0.863 \\
\hline 8 & creatininemia 1 & 5.84 & 0.284 & 14 & 0.417 \\
\hline 9 & creatininemia 2 & 6 & 0.273 & 14 & 0.429 \\
\hline 9 & weight & 5.48 & 0.214 & 17 & 0.322 \\
\hline 10 & dialysis volume & 5.04 & 0.233 & 10 & 0.504 \\
\hline 11 & $\begin{array}{l}\text { clearance creatinine by ideal creatinine } \\
\text { according to age and age week }\end{array}$ & 4.28 & 0.178 & 8 & 0.535 \\
\hline 1$)$ ranges of scores versus coefficients of variations R $0.812, \mathrm{R}^{2} 0.659, \mathrm{p}=0.000746$ & & \\
\hline
\end{tabular}


World Journal of Research and Review (WJRR)

ISSN:2455-3956, Volume-7, Issue-3, September 2018 Pages 32-52

2) ranges of scores versus coefficients of variations and number of correlations: $R 0.902, R^{2} 0.814, p=0.00023$

3 ) $t$ ranges of scores/number of correlations versus number of correlations: $R 0.832, R^{2} 0.692, p=0.00042$

\begin{tabular}{|c|c|}
\hline \multicolumn{2}{|r|}{ Table XXIX - Comparison ot the same regressions males versus females } \\
\hline males & 1) ranges of the scores versus the coefficients of variation : $R 0.848, R^{2} 0.720, p=0.00097$ \\
\hline females & 1) the ranges of the scores versus the coefficients of variations $R 0.812, R^{2} 0.659, p=0.000746$ \\
\hline males & 2) the ranges of the scores versus the coefficients of variations and the number of the correlations: $R 0.848 . R^{2}=0.720, p=0.0061$ \\
\hline females & 2) the ranges of the scores versus the coefficients of variations and the number of the correlations: $R 0.902, R^{2} 0.814, p=0.00023$. \\
\hline males & 3) the ranges of scores/number of correlations versus the number of the correlations: $R \quad 0.709, R^{2} \quad 0.702, p=0.015$ \\
\hline females & 3) the ranges of scores/number of correlations versus the number of the correlations: $R 0.832, R^{2} 0.692, P=0.00042$ \\
\hline
\end{tabular}

As in males, the degrees of the correlations, based on $\mathrm{p}$ values, were made numerically comparable by attributing a score to them, with the aim, as previously mentioned, to evaluate the power of the correlations. Based on this, it is possible to state the most effective correlation, which is contained in Table XXVI. The considerations on the regressions concerning males may be applied to the regressions concerning females because the regressions concerned the same variables and because the results of regressions in males are very close to the results of regressions in females, as shown in Table XXVIII.

The relevance of the results of the regressions shown in Table XXIX was evaluated by measuring and comparing the distance of $\mathrm{R}$ values from 1 because 1 is the total correspondence between predicting variables and predicted variables. The consistent results are shown in Table XXX

\begin{tabular}{|c|c|c|c|c|c|}
\hline \multicolumn{6}{|c|}{$\begin{array}{l}\text { Table XXX - males and females - Comparisons of the results of the regressions in Table XXVIII } \\
\text { on the basis of R values }\end{array}$} \\
\hline \multirow{2}{*}{$\begin{array}{l}\mathrm{R} \text { values } \\
\text { males }\end{array}$} & \multirow{2}{*}{$\begin{array}{l}\mathrm{R} \text { values } \\
\text { females }\end{array}$} & \multicolumn{2}{|c|}{ difference from 1} & \multicolumn{2}{|c|}{ difference $\%$ from 1} \\
\hline & & males & females & males & females \\
\hline 0.848 & 0.812 & 0.52 & 0.188 & 84.8 & $8 ., 2$ \\
\hline 0.848 & 0.812 & 0.152 & 0.188 & 84.8 & 81.2 \\
\hline 0.645 & 0.902 & 0.355 & 0.098 & 64,5 & 90.2 \\
\hline 0.848 & 0.832 & 0.152 & 0.168 & 84.8 & 83.2 \\
\hline \multirow[t]{3}{*}{0.709} & 0.832 & 0.291 & 0.168 & 70.9 & 83.2 \\
\hline & mean & 0.22 & 0.162 & 77.96 & 83.8 \\
\hline & SD & 0.096 & 0.037 & 9.64 & 3.71 \\
\hline $\mathrm{T}$ test & difference from 1 & \multicolumn{4}{|c|}{$\mathrm{T}$ value $=1.26, \mathrm{p}$ value $=0.263$} \\
\hline T test & difference $\%$ from 1 & \multicolumn{4}{|c|}{$\mathrm{T}$ value $=1.26, \mathrm{p}$ value $=0.262$} \\
\hline
\end{tabular}

The differences between the $\mathrm{R}$ values for males versus females were not significant, on the basis of the actual values and on the basis of the percentage differences. Therefore, notwithstanding the significant differences of somatic dimensions (height, weight and BSA), in which the differences of excreted creatinine have to be comprised because of undirected expression of muscle mass, and the differences of clearances, shown in Tables I, II, III, and IV, the following data concerning the correlations did not point out differences concerning the scores, as shown in the following tables, Tables XXXI A and XXXI B, with the only exception being the total daily creatinine excretion.

Table XXXI A- Comparison of males versus females of the values of the scores the basis of the basal variables

\begin{tabular}{|c|c|c|c|c|c|c|}
\hline \multicolumn{2}{|c|}{ males and females } & \multirow{3}{*}{$\begin{array}{c}\text { basal } \\
\text { variable } \\
\text { age }\end{array}$} & \multirow{3}{*}{\begin{tabular}{|c}
$\begin{array}{c}\text { correlated } \\
\text { variables: number }\end{array}$ \\
23 \\
22
\end{tabular}} & \multirow{3}{*}{$\begin{array}{l}\text { mean } \pm \text { SD of scores } \\
5.17 \pm 1.7 \\
5.45 \pm .1 .63 \\
\end{array}$} & \multirow{3}{*}{\begin{tabular}{|c}
$\begin{array}{c}\mathrm{T} \\
\text { value }\end{array}$ \\
-0.56
\end{tabular}} & \multirow{3}{*}{$\begin{array}{l}\mathrm{p} \text { value } \\
0.576\end{array}$} \\
\hline \multirow{2}{*}{1} & males & & & & & \\
\hline & females & & & & & \\
\hline \multirow{2}{*}{2} & males & \multirow{2}{*}{ height } & 9 & $4.56 \pm 1.33$ & \multirow{2}{*}{-0.22} & \multirow{2}{*}{0.826} \\
\hline & females & & 14 & $4.71 \pm 1.9$ & & \\
\hline \multirow{2}{*}{3} & males & \multirow{2}{*}{ weight } & 6 & $6.33 \pm 1.03$ & \multirow{2}{*}{0.15} & \multirow{2}{*}{0.884} \\
\hline & females & & 17 & $6.41 \pm 1.37$ & & \\
\hline \multirow{2}{*}{4} & males & \multirow{2}{*}{ BSA } & 3 & $5 \pm 2$ & \multirow{2}{*}{-0.51} & \multirow{2}{*}{0.66} \\
\hline & females & & 19 & $5.63 \pm 1.89$ & & \\
\hline
\end{tabular}


45 Males and 94 Females Undergoing Chronic Peritoneal Dialysis: Comparison and Correlation of Their Dialytic Treatment and Body Composition

\begin{tabular}{|c|c|c|c|c|c|c|}
\hline \multirow{2}{*}{5} & males & \multirow{2}{*}{ BMI } & 10 & $4.8 \pm 1.99$ & \multirow{2}{*}{-0.81} & \multirow{2}{*}{0.427} \\
\hline & females & & 14 & $5.43 \pm 1.6$ & & \\
\hline \multirow{2}{*}{6} & males & \multirow{2}{*}{ a creatininemi } & 10 & $5.4 \pm 1.84$ & \multirow{2}{*}{-0.15} & \multirow{2}{*}{0.88} \\
\hline & females & & 28 & $5.5 \pm 1.5$ & & \\
\hline
\end{tabular}

\begin{tabular}{|c|c|c|c|c|c|c|}
\hline \multicolumn{7}{|c|}{$\begin{array}{l}\text { Table XXXI } \mathrm{B}-\text { Comparison } \\
\text { on the basis of the basal variables }\end{array}$} \\
\hline $\begin{array}{r}\text { mal } \\
\text { female }\end{array}$ & and & basal variable & $\begin{array}{l}\text { correlated variables: } \\
\text { number }\end{array}$ & $\begin{array}{c}\text { mean } \pm S \\
D \text { of scores }\end{array}$ & $\begin{array}{c}\mathrm{T} \\
\text { value }\end{array}$ & $\mathrm{p}$ value \\
\hline \multirow{2}{*}{7} & males & \multirow{2}{*}{ Cockroft } & 19 & $5^{5.63 \pm 1}$ & \multirow{2}{*}{-0.76} & \multirow{2}{*}{0.455} \\
\hline & females & & 11 & $64^{6.09 \pm 1 .}$ & & \\
\hline \multirow[b]{2}{*}{8} & males & \multirow{2}{*}{ dialysis volume } & 9 & $4.33 \pm 1$ & \multirow[b]{2}{*}{-2.06} & \multirow[b]{2}{*}{0.056} \\
\hline & females & & 10 & $6^{5.4 \pm 1.2}$ & & \\
\hline \multirow{2}{*}{9} & males & \multirow{2}{*}{ total creatinine clearance week } & 14 & $07^{6.71 \pm 1 .}$ & \multirow{2}{*}{1.79} & \multirow{2}{*}{0.108} \\
\hline & females & & 7 & $51^{5.57 \pm 1 .}$ & & \\
\hline \multirow{2}{*}{10} & males & \multirow{2}{*}{ total excreted creatinine/die } & 17 & $87^{6.53 \pm 0 .}$ & \multirow{2}{*}{3.78} & \multirow{2}{*}{0.003} \\
\hline & females & & 10 & $5^{4.4 \pm 1.6}$ & & \\
\hline \multirow{2}{*}{11} & males & \multirow{2}{*}{$\begin{array}{l}\text { ideal creatinine clearance } \\
\text { according to height and age week }\end{array}$} & 9 & $73^{5.67 \pm 1 .}$ & \multirow{2}{*}{0.48} & \multirow{2}{*}{0.64} \\
\hline & females & & 8 & $6 \pm 1.07$ & & \\
\hline
\end{tabular}

The consistent mean and standard deviation of the scores resulted in $6.53 \pm 0.87$ for males and $4.4 \pm 1.65$ for females; the sum of the scores for males was 111 , and for females, it was 44 . Therefore, excreted creatinine/die is more closely correlated with the remaining variables in males than in females. The following table, Table XXXII, compares the number of attained correlations, males versus females, taking into account the different numerousness of the studied populations, 45 males versus 94 females.

\begin{tabular}{|c|c|c|c|c|}
\hline \multicolumn{5}{|c|}{$\begin{array}{l}\text { Table XXXII - Comparison of males versus females of the number of attained } \\
\text { correlations }\end{array}$} \\
\hline \multicolumn{3}{|c|}{ correlated variables number } & \multicolumn{2}{|c|}{ indexed on population } \\
\hline $\mathrm{n}$ & males & females & $5^{\text {males/4 }}$ & females/94 \\
\hline 1 & 23 & 22 & 0.51 & 0.234 \\
\hline 2 & 9 & 17 & 0.2 & 0.181 \\
\hline 3 & 6 & 19 & 0.133 & 0.202 \\
\hline 4 & 3 & 14 & 0.067 & 0.149 \\
\hline 5 & 10 & 14 & 0.222 & 0.149 \\
\hline 6 & 10 & 28 & 0.222 & 0.298 \\
\hline mean & 10.17 & 19 & 0.226 & 0.202 \\
\hline \multirow[t]{5}{*}{ SD } & 6.85 & 5.37 & 0.152 & 0.057 \\
\hline & \multicolumn{2}{|l|}{$\mathrm{T}$ test } & \multicolumn{2}{|l|}{$\mathrm{T}$ test } \\
\hline & \multicolumn{2}{|c|}{$\mathrm{T}$ Value } & \multicolumn{2}{|l|}{$\mathrm{T}$ Value } \\
\hline & \multicolumn{2}{|l|}{-2.48} & \multicolumn{2}{|l|}{0.45} \\
\hline & \multicolumn{2}{|c|}{$\mathrm{p}=0.035$} & \multicolumn{2}{|c|}{$\mathrm{p}=0.665$} \\
\hline
\end{tabular}


In the first partition of the table, the number of significant correlations attained by the females' data was significantly greater than that attained by males: taking into account the possible greater chance to have more significant correlations based on the double population with respect to that of males, the number of correlations was indexed by the numerousness of the respective population, and the indexed values show an insignificant difference between males and females.

The tables Table V to Table XIV contain the correlations and the consistent scores concerning males, and Table XVI to Table XXVI concern females. The following tables report the results of $\mathrm{T}$ values and the scores of the correlations of the tables above; this allowing us to directly compare the degree of the correlations of males versus females by comparing the $\mathrm{T}$ values and the values of the consistent scores.

Table XXXIII - Summary of the T values and of the scores attained by the correlations of males and females and their comparison

\begin{tabular}{|c|c|c|c|c|c|c|c|c|}
\hline correlating variables & males & females & $\begin{array}{c}\mathrm{T} \\
\text { value }\end{array}$ & $\mathrm{p}$ & males & females & $\begin{array}{c}\mathrm{T} \\
\text { value }\end{array}$ & $\mathrm{p}$ \\
\hline age & & & & & \multicolumn{4}{|l|}{ scores } \\
\hline number of correlations & 23 & 22 & $\begin{array}{c}\mathrm{T} \\
\text { value }\end{array}$ & $\mathrm{p}$ & 23 & 22 & $\begin{array}{c}\mathrm{T} \\
\text { value }\end{array}$ & $\mathrm{p}$ \\
\hline statistics & $5.26 \pm 2.69$ & $-0.374 \pm 0.458$ & 9.9 & $00^{0.0}$ & $5.7 \pm 1.7$ & $3^{5.45 \pm 1.6}$ & 0.5 & $17^{0.6}$ \\
\hline height & & & & & \multicolumn{4}{|l|}{ scores } \\
\hline number of correlations & 19 & 14 & & & 19 & 14 & $\begin{array}{c}\mathrm{T} \\
\text { value }\end{array}$ & $\mathrm{p}$ \\
\hline statistics & $0.449 \pm 0.1$ & $0.321 \pm 0.271$ & 8.95 & $00^{0.0}$ & $5 \pm 1.49$ & $4.71 \pm 1.9$ & 0.47 & $40^{0.6}$ \\
\hline weight & & & & & \multicolumn{4}{|l|}{ scores } \\
\hline number of correlations & 6 & 17 & $\begin{array}{c}\mathrm{T} \\
\text { value }\end{array}$ & $\mathrm{p}$ & 6 & 17 & $\begin{array}{c}\mathrm{T} \\
\text { value }\end{array}$ & $\mathrm{p}$ \\
\hline statistics & $0.648 \pm 0.227$ & $0.476 \pm 0.316$ & 1,43 & $78^{0.1}$ & $36.33 \pm 1.0$ & $7^{6.41 \pm 1.3}$ & -0.15 & $8^{0.8}$ \\
\hline
\end{tabular}

Table XXXIII - Summary of the T values and of the scores attained by the correlations of males and females and their comparison following data

\begin{tabular}{|c|c|c|c|c|c|c|c|c|}
\hline \multirow{2}{*}{$\begin{array}{l}\text { BSA } \\
\text { number of correlations }\end{array}$} & \multirow[b]{2}{*}{3} & \multirow[b]{2}{*}{19} & \multirow[b]{2}{*}{$\begin{array}{c}\mathrm{T} \\
\text { value }\end{array}$} & \multirow[b]{2}{*}{$\mathrm{p}$} & \multicolumn{4}{|l|}{ scores } \\
\hline & & & & & 3 & 19 & $\begin{array}{c}\mathrm{T} \\
\text { value }\end{array}$ & $\mathrm{p}$ \\
\hline statistics & $0.44 \pm 0.089$ & $0.29 \pm 0.319$ & 1,68 & $19^{0.1}$ & $5 \pm 2$ & $5.63 \pm 1.8$ & -0.51 & ${ }^{6}{ }^{0.6}$ \\
\hline BMI & & & & & \multicolumn{4}{|l|}{ scores } \\
\hline number of correlations & 10 & 14 & $\begin{array}{c}\mathrm{T} \\
\text { value }\end{array}$ & $\mathrm{p}$ & 10 & 14 & $\begin{array}{c}\mathrm{T} \\
\text { value }\end{array}$ & $\mathrm{p}$ \\
\hline statistics & $-015 \pm 0.45$ & $0.228 \pm 0.365$ & $-2,19$ & $44^{0,0}$ & $4.8 \pm 1.99$ & $5.43 \pm 1.6$ & $-0,83$ & $20^{0.4}$ \\
\hline creatininemia & & & & & \multicolumn{4}{|l|}{ scores } \\
\hline number of correlations & 10 & 28 & $\begin{array}{c}\mathrm{T} \\
\text { value }\end{array}$ & $\mathrm{p}$ & 10 & 28 & $\begin{array}{c}\mathrm{T} \\
\text { value }\end{array}$ & $\mathrm{p}$ \\
\hline statistics & $-0.136 \pm 0.5$ & $-0.11 \pm 0.471$ & 0.14 & $88^{0.8}$ & $5.4 \pm 1.84$ & $5.5 \pm 1.5$ & -0.15 & $80^{0.8}$ \\
\hline
\end{tabular}

Table XXXIV - Summary of the T values and of the scores attained by the correlations of males and females and their comparison

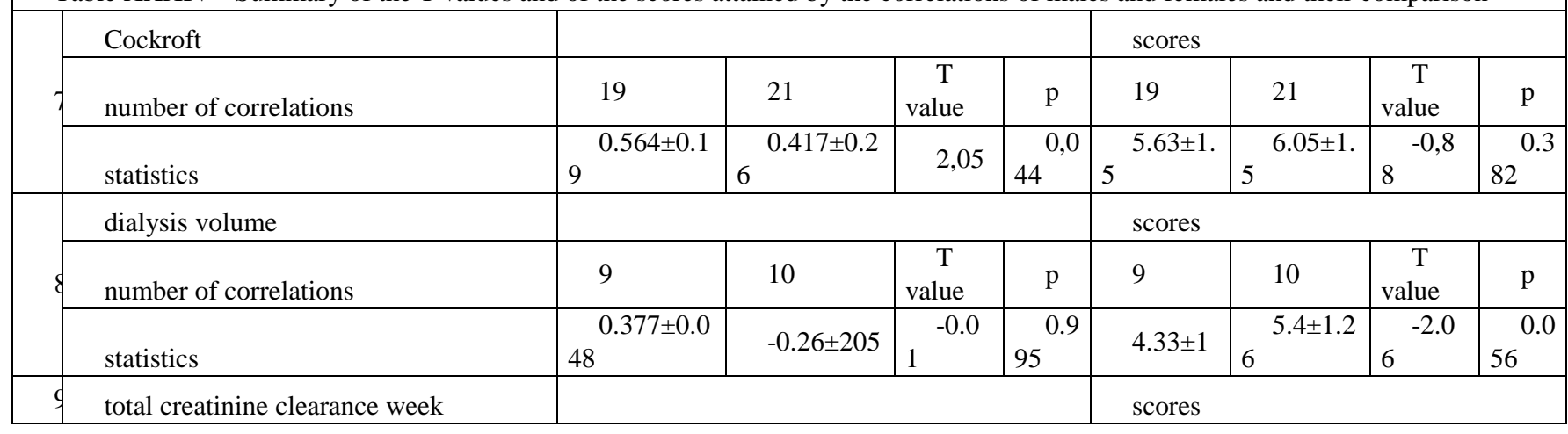


45 Males and 94 Females Undergoing Chronic Peritoneal Dialysis: Comparison and Correlation of Their Dialytic Treatment and Body Composition

\begin{tabular}{|c|c|c|c|c|c|c|c|c|c|}
\hline & number of correlations & 14 & 7 & $\begin{array}{c}\mathrm{T} \\
\text { value }\end{array}$ & $\mathrm{p}$ & 14 & 7 & $\begin{array}{c}\mathrm{T} \\
\text { value }\end{array}$ & $\mathrm{p}$ \\
\hline & statistics & $36^{0.514 \pm 0.5}$ & $64^{0.037 \pm 0.4}$ & 2.11 & $55^{0.0}$ & $0^{6.71 \pm 1}$ & $515.57 \pm 1$. & 1.79 & $08^{0.1}$ \\
\hline \multirow{3}{*}{0} & totale excreted creatinine/die & & & & & \multicolumn{4}{|l|}{ scores } \\
\hline & number of correlations & 17 & 10 & $\begin{array}{c}\mathrm{T} \\
\text { value }\end{array}$ & $\mathrm{p}$ & 17 & 10 & $\begin{array}{c}\mathrm{T} \\
\text { value }\end{array}$ & $\mathrm{p}$ \\
\hline & statistics & $16^{0.399 \pm 0.5}$ & $19^{0.178 \pm 0.2}$ & 1.13 & $72^{0.2}$ & $87^{6.53 \pm 0 .}$ & $5^{4.4 \pm 1.6}$ & 3.78 & $03^{0.0}$ \\
\hline \multirow{3}{*}{1} & $\begin{array}{l}\text { ideal creatinine according to age and } \\
\text { height week }\end{array}$ & & & & & \multicolumn{4}{|l|}{ scores } \\
\hline & number of correlations & 9 & 8 & $\begin{array}{c}\mathrm{T} \\
\text { value }\end{array}$ & $\mathrm{p}$ & 9 & 8 & $\begin{array}{c}\mathrm{T} \\
\text { value }\end{array}$ & $\mathrm{p}$ \\
\hline & statistics & $0.59 \pm 0.41$ & $09^{0.477 \pm 0.2}$ & 0.73 & $81^{0.4}$ & $73^{5.67 \pm 1}$ & $6 \pm 1.07$ & $8^{-0.4}$ & $40^{0.6}$ \\
\hline
\end{tabular}

Tables XXXIII and XXXIV resume the T values and their standard deviations attained by the correlations of males and females. Their content shows the results of $\mathrm{T}$ values and consistent standards deviation of the attained $\mathrm{T}$ Values. The same was operated for the consistent scores. The results were compared males versus females. In the tables it is possible to point out that males and females have insignificant difference for $\mathrm{T}$ values of the correlations concerning the basal variables weight, BSA, creatininemia, dialysis volume, total creatinine clearance week, total excreted creatinine/die, and ideal creatinine according to age and weight/week. On the contrary, the following basal variables resulted to have significant difference of $\mathrm{T}$ values : age, height, BMI, and clearance according to Cockroft, therefore 4 basal variables out of 11 differed between males and females. The attained $\mathrm{T}$ values had a greater size in males in 9 comparison out of 11 , the females having better results for basal variables concerning BMI and dialysis volume. The prevalence of females for BMI, notwithstanding the known greater body size of males, could likely to be linked to the prevalence of body water mass in females (see below in the topic "Total body water")

\section{Lean Body Mass}

This section includes the evaluation of the lean body mass (LBM), the dry mass of the body. The size of LBM may be estimated by mathematical calculation according to formulae or by directly measuring it by Body Impedance Analysis (BIA): the data available in the database does not include a BIA estimation of dry mass for males and females, therefore LBM sizes had to be calculated. This may be realized according to different available formulae, by Boer, by James, and by Hume. The formulae by Boer were selected because they were more recently proposed [3]. LBM is estimable by two different formulae according to gender: males, $2.447-0.09516 \mathrm{x}$ age $+0.1074 \mathrm{x}$ height $+0.3362 \mathrm{x}$ weight; females, $-2.097+0.1069 \mathrm{x}$ height + $0.2466 \mathrm{x}$ weight. The consistent results and comparisons of males versus females are shown in Table XXXV .

\begin{tabular}{|c|c|c|c|}
\hline \multicolumn{4}{|c|}{ Table XXXV - LBM males versus females } \\
\hline Males & females & $\mathrm{T}$ value & $\mathrm{P}$ \\
\hline $57.04 \pm 5.5$ & $40.57 \pm 4.34$ & 17.63 & 0.000 \\
\hline \multicolumn{4}{|c|}{ LBM as \%of weight } \\
\hline Males & females & $\mathrm{T}$ value & 0.000 \\
\hline $24.49 \pm 5.67$ & $33.6 \pm 11.09$ & -6.41 & 0.000 \\
\hline \multicolumn{4}{|c|}{ LBM/BMI males versus females } \\
\hline $2.2 \pm 0.38$ & $1.66 \pm 0.32$ & 8.24 & 0.000 \\
\hline
\end{tabular}

LBM may also be calculated on the basis of creatininemia, by the equation $\mathrm{LBM}=1.8 \mathrm{x}$ creatininemia +41.78 . This equation is the result of the regression LBM versus serum creatinine, $\mathrm{R} 0.55, \mathrm{R}^{2} 0.303, \mathrm{p}<0.0001$, where LBM sizes were determined by total body potassium measurement, Keshaviah et al. [4]. Their study was based on 114 subjects, of which 17 were in normal conditions, 26 were undergoing hemodialysis and 71 were undergoing peritoneal dialysis, both in satisfying and stable conditions. An LBM by creatininemia was performed, applied to the studied patients of this work, with the results shown in Table XXXVI

\begin{tabular}{|l|l|l|}
\hline \multicolumn{2}{|c|}{ Table XXXVI - Comparisons of different LBMs for males vs females } \\
\hline & males & females \\
\hline LBM by Boer & $57.04 \pm 5.5$ & $40.57 \pm 4.34$ \\
\hline LBM by serum creatinine & $61.41 \pm 5.99$ & $58.08 \pm 4.32$ \\
\hline T value & -3.6 & -27.72 \\
\hline
\end{tabular}


World Journal of Research and Review (WJRR)

ISSN:2455-3956, Volume-7, Issue-3, September 2018 Pages 32-52

\begin{tabular}{|c|c|c|}
\hline $\mathrm{p}$ & 0.001 & 0.000 \\
\hline \multicolumn{3}{|c|}{ Table XXXVI - Comparisons of different LBMs - following data } \\
\hline & males & females \\
\hline LBM by Boer & $57.04 \pm 5.5$ & $40.57 \pm 4.34$ \\
\hline T value & 17.63 & \\
\hline $\mathrm{p}$ & 0.000 & \\
\hline LBM by serum creatinine & $61.41 \pm 5.99$ & $58.08 \pm 4.32$ \\
\hline T value & 3.64 & \\
\hline $\mathrm{p}$ & 0.001 & \\
\hline
\end{tabular}

When comparing males versus males and females versus females or comparing males versus females, the different methods to evaluate the size of LBM result in significantly different values when based on the Boer formula or based on creatininemia: these differences are not based on the difference of gender but on the estimation method. The more approximated estimation likely could be that based on creatinine kinetics [4], due to the relationship of creatininemia with produced creatinine mass, that is the direct expression of muscle mass, and on the relationship of LBM with albumin [4], that is expression of bodily nutrition, the base for the muscle mass. LBM by serum creatinine regressed versus LBM by Boer does not correlate for males and for females, while a significant correlation was attained when indexing the values of items by BMI, males $\mathrm{R} 0.778, \mathrm{R}^{2} 0.605, \mathrm{p}=$ $3.09 * e^{-10}$, females $\mathrm{R} 0.665, \mathrm{R}^{2} 0.442, \mathrm{p}=2,7 * e^{-13}$. The results attained only if indexing on BMI show that LBM is strongly related to the body structure: for males, LBM by Boer and by serum creatinine directly correlate with BMI, Boer, R $0.413, \mathrm{R}^{2}$ $0.17, p=0.0048$, serum creatinine $R 0.388, R^{2} 0.151, p=0.0088$, whereas for females LBM by Boer and by serum creatinine does not correlate with BMI, probably because the weight of females, on which bases BMI, includes very frequently a larger amount of fat respect to muscle mass that in males and a larger amount of water content: see below in Table XXXVIII, line 2.

The body water content

The size according to gender and the difference of LBM between males and females are rationally correlated with the size of body water. The lack of exact data about body water induced to use an estimation of it, based on the formula by Watson [5], that is, for males: total body water $=2.447-0.09516 \mathrm{x}$ age $+0.1074 \mathrm{x}$ height $+0.3362 \mathrm{x}$ weight, and for females: total body water $=-2.097+0.1069 \times$ height $+0.2466 \mathrm{x}$ weight. The values of estimated total body water $(\mathrm{TBW})$ and of the relationship LBM - TBW are shown in the following table, Table XXXVIII.

Table XXXVIII - Total body water (TBW) by Watson and LBM, males versus females

\begin{tabular}{|c|c|c|c|c|}
\hline \multirow[b]{2}{*}{ Variables } & \multicolumn{2}{|c|}{ data: mean \pm SD } & \multicolumn{2}{|c|}{ statistics } \\
\hline & 45 males & 94 females & $\begin{array}{c}\mathrm{T} \\
\text { value }\end{array}$ & $\mathrm{p}$ \\
\hline TBW & $40.83 \pm 4.49$ & $30.2 \pm 2.99$ & 14.42 & 0.000 \\
\hline TBW as $\%$ of weight & $46.03 \pm 4.01$ & $51.11 \pm 3.5$ & -7.27 & 0.000 \\
\hline \multicolumn{5}{|c|}{ Table XXXVIII - Total body water (TBW) by Watson and LBM, males versus females - following data } \\
\hline weight minus TBW & $35.41 \pm 7.78$ & $32.25 \pm 7.38$ & 2.28 & 0.025 \\
\hline LBM by Boer & $57.04 \pm 5.5$ & $40.57 \pm 4.34$ & 17.63 & 0.000 \\
\hline LBM by serum creatinine & $61.41 \pm 5.99$ & $58.1 \pm 4.32$ & 3.32 & 0.001 \\
\hline (weight - TBW) as \% of LBM by Boer & $38.36 \pm 9.58$ & $20.05 \pm 18.3$ & 7.74 & 0.000 \\
\hline (weight - TBW) as \% of LBM by serum creatinine & $42.25 \pm 11,96$ & $44.4 \pm 12.37$ & 0.98 & 0.329 \\
\hline LBM by Boer as \% of weight & $24.49 \pm 5.67$ & $33.6 \pm 11,1$ & -6.4 & 0.000 \\
\hline LBM by serum creatinine as $\%$ of weight & $18.1 \pm 11.6$ & $4.73 \pm 15.9$ & 5.61 & 0.000 \\
\hline
\end{tabular}

The table shows that TBW size is significantly greater in males (line1), but significantly greater in females as a percentage of body weight (line 2), that is to say, the content of water is greater in females. The file 6 shows that the dry mass ((weight - TBW) is widely greater in males as percentage of LBM by Boer, whereas no difference of dry mass males females result as percentage of LBM by serum creatinine (line 7), notwithstanding the significant difference existing between males and females concerning LBM by serum creatinine, $\mathrm{T}$ value $=3.32, \mathrm{p}=0.001$. Finally, file 8 shows that females should have a significant greater LBM as percentage of weight respect to males on base of Boer estimation: this result should be considered uncertain, because indexing LBM by Boer on BMI, that is to say according to the body structure, LBM is significantly lower in females, $1.66 \pm 0.32$ versus $2.2 \pm 0.38$ in males, $\mathrm{T}$ value $=8.24, \mathrm{p}=0.000$, and taking into account the very great difference shown in line 9, based on LBM estimated by serum creatinine, all this likely confirms the better suitability to use serum creatinine for LBM 
estimation. From the above, it is possible to conclude that males have greater dry mass and females greater body water with respect to their weight.

The correlations tables.

The tables showing in details the correlations were 10 table for males and for females. The following tables, Tables XXXIX A and XXXIX B, report the degree of the correlations attained by males and females and shows a comparison of the degrees of correlations and of the consistent scores.

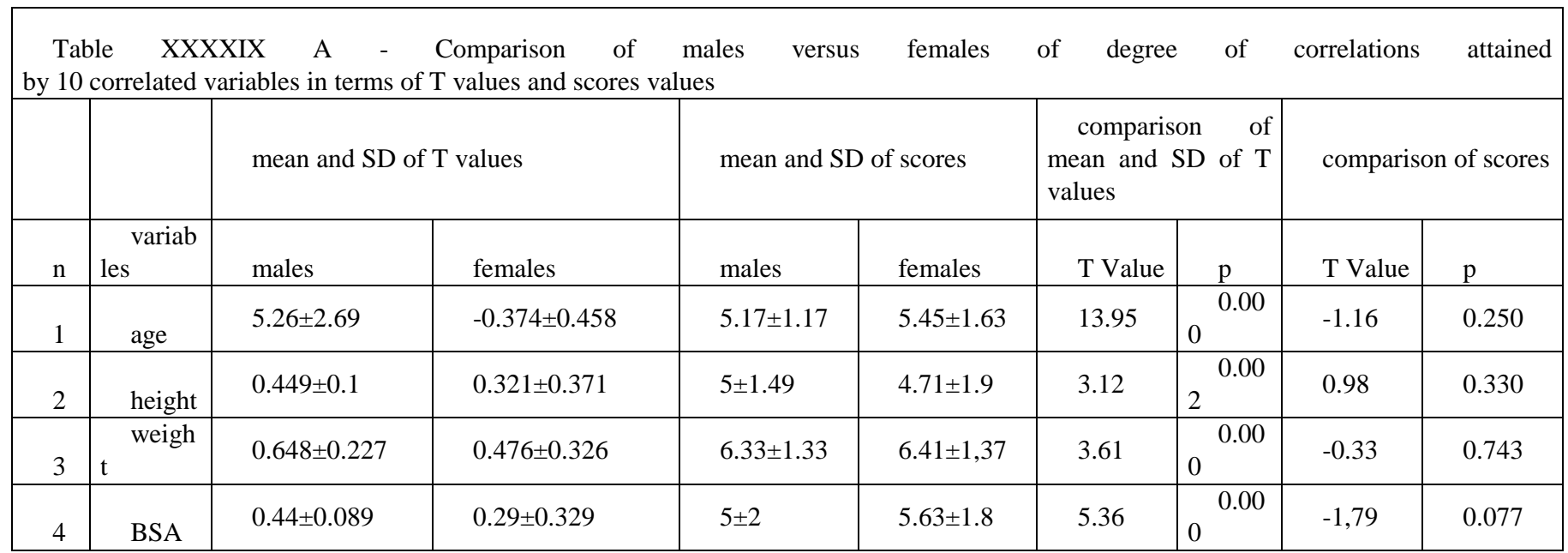

\begin{tabular}{|c|c|c|c|c|c|c|c|c|c|}
\hline \multicolumn{10}{|c|}{$\begin{array}{l}\text { Table XXXIX } \mathrm{B}-\mathrm{C} \text { Comparison of males } \\
\text { by } 10 \text { correlating variables in terms of } \mathrm{T} \text { values and scores values }\end{array}$} \\
\hline & & \multicolumn{2}{|c|}{ mean and $\mathrm{SD}$ of $\mathrm{T}$ values } & \multicolumn{2}{|c|}{ mean and SD of scores } & \multicolumn{2}{|c|}{$\begin{array}{l}\quad \text { comparison } \\
\text { of mean and } \mathrm{SD} \\
\text { of } \mathrm{T} \text { values }\end{array}$} & \multicolumn{2}{|c|}{$\begin{array}{l}\text { comparison of } \\
\text { scores }\end{array}$} \\
\hline 5 & BMI & $-0.15 \pm 0.45$ & $0.228 \pm 0.365$ & $4.8 \pm 1.99$ & $5.43 \pm 1.6$ & -4.91 & 0.000 & -1.86 & 0.068 \\
\hline 6 & creatininemia & $-0.136 \pm 0.5$ & $-0.11 \pm 0.471$ & $5.4 \pm 1.84$ & $5.5 \pm 1.5$ & $\begin{array}{l}-0.29 \\
\end{array}$ & 0.771 & -0.32 & 0.752 \\
\hline 7 & Cockroft & $0.564 \pm 0.19$ & $0.417 \pm 0.26$ & $5.63 \pm 1.5$ & $6.05 \pm 1.5$ & 3.77 & 0.000 & -1.54 & 0.126 \\
\hline 8 & dialysis volume & $0.377 \pm 0.048$ & $-0.26 \pm 0.205$ & $4.33 \pm 1$ & $5.4 \pm 1.26$ & $4^{28.5}$ & 0.000 & -5.41 & 0.000 \\
\hline 9 & total excreted creatinine/die & $0.399 \pm 0.516$ & $0.178 \pm 0.219$ & $6.53 \pm 0.87$ & $4.4 \pm 1.65$ & 2.76 & 0.008 & 9.95 & 0.000 \\
\hline $0^{1}$ & total creatinine clearance week & $0.514 \pm 0.536$ & $0.037 \pm 0.464$ & $6.71 \pm 1.07$ & $5.57 \pm 1.51$ & 5.12 & 0.000 & 5.11 & 0.000 \\
\hline
\end{tabular}

In Tables XXXIX A and XXXIX B, it is possible to note from the differences between $\mathrm{T}$ values that the correlations concerning male data were much more significant than those concerning females with the only exception for creatininemia The differences between scores present a different outcome, because the differences between males and females concerned only the correlations based on dialysis volume, total excreted creatinine/die, and total creatinine clearance week, thus signifying that the $\mathrm{p}$ values for the remaining correlations were not significantly different for males versus females, notwithstanding the significant differences of $\mathrm{T}$ values.

\section{DISCUSSION AND CONCLUSIONS}

The aim of the present paper was to compare a wide selection of data of 45 males versus those of 94 females, fundamentally concerning dialytic treatment and creatinine mass, as real dialytic treatment and as actual mass or ideal mass of creatinine, and to be differently indexed on BSA or $\mathrm{BMI}, \mathrm{BMI}$ resulting the only selected indexation: comparing males versus females, twelve variables out forty variables no significantly differed: therefore, considering in a whole the signification of the not different variables, males and females have very similar age, similar body structure because the not different BMI, similar efficacy of treatment. The relevance of age was pointed out by applying the Cockroft formula: based on similar ages of males and females, the values of the creatinine clearances calculated by the Cockroft formula resulted strongly similar, but modifying the difference of ages by assuming an unmodified age for males and an increased age for females $(+15 \%)$, the final Cockroft value for females significantly differed from that of males. The degree of a correlation between each basal variable and the remaining variables is clearly represented by the difference between the predicted items and the actual items: their statistical comparison resulted for males and females in $\mathrm{T}$ value $=0, p=1$. Scores were attributed to $p$ values of correlations to mathematically compare the correlations and the ratio mean of the scores/standard deviation measured the magnitude of the dispersion of the scores, that is to say the width of the range of the significance of the correlations. The evaluation of this range allowed to know the relevance of the 
correlations for each basal variable. BMI and BSA resulted the basal variables generating the greatest ranges and the greatest coefficients of variation; the lowest values were from the basal variable total excreted creatinine/die. The high significance of correspondence between the ranges of the scores and the consistent coefficients of variation showed that the ranges of the scores likely had a high variance of distribution. The differences between $\mathrm{R}$ values of the regressions and $\mathrm{R}=1$, the theoretical full correspondence between predicting and predicted items, compared males versus females resulted not significant, on the base of actual values and on the base of percentage differences, notwithstanding the significant differences of somatic dimensions of males versus females (height, weight and BSA) with exception for BMI. Lean Body Mass was calculated on base of Boer formula and on base of serum creatinine. LBMs by Boer correlated for males and females with LBM by serum creatinine only if indexed on BMI, this showing that LBM was strongly related to the body structure. Based on the results of the degree of the correlations attained by males and females, it was possible to note from the differences between $\mathrm{T}$ values that the correlations concerning males data resulted strongly more significant than those concerning females with the only exception for creatininemia, this pointing out a greater dispersion of data in females. The size according to gender and the difference of LBM between males and females resulted correlated with the size of body water, estimated according to the formula by Watson. Total body water (TBW) resulted significantly greater in males, because the somatic greater size of males, but it was significantly greater in females as percentage of body weight. From the above, it was possible to conclude that males have greater dry mass and females greater body water with respect to their weight, that is to say that the extracellular body water was greater in females. From all of the above, it is possible to fundamentally conclude the following:

1) No differences for males versus females resulted for age, relationship weight/height in terms of BMI, and efficacy of treatment.

2) The difference of age may be relevant for the size of creatinine clearance, as shown by creatinine clearance by Cockroft.

3) The Cockroft formula results in creatinine clearance that is highly correlated with measured creatinine clearance, but its results overestimate the actual creatinine clearance.

4) Lean Body Mass is proportional to BMI.

5) The scores values demonstrate that, in correlations the variables correlated with the basal variable have a high variability of item distribution.

6) The correlations for males were more significant than for females, probably because of greater variability of the items distribution of basal data for males.

7) Dry mass is significantly greater in males, and the body water is greater in females in terms of percentage of weight.

\section{REFERENCES}

[1] Ruggieri G. A comparison of body composition, residual biological function and dialytic treatment of 20 males and 19 females undergoing chronic peritoneal dialysis. WJRR, 7,1: 2018. 28 - 35
[2] Cockroft DW, Gault MH. Prediction of creatinine clearance from serum creatinine. Nephron 1976, 16: 31 -34

[3] Boer P. Estimated lean body mass as an index for normalization of body fluid volumes in man. Am J Physiol 1984; 247: F632-5

[4] Keshaviah PR, Nolph KD, Moore H., Prowant B, Emerson PF, Meyer M, Twardowsky ZJ, Khanna R, Ponferrada L, and Collins A. Lean Body Mass estimation by creatinine kinetics. J. Am. Soc. Nephrol. 1994; 4: 1475- 1485 